\title{
調查報告
}

\section{アクアライン開通後における木更津市の地理的 特徵・構造と地域的課題 一特に交通的・人口的・商業的側面を中心に一}

Geographic Characteristics and Structural and Regional Issues of Kisarazu after the Opening of the Aqua-Line: Focus on Traffic, Population, and Commerce

\section{牛垣 雄矢・久保 薰・坂本 律樹・関根 大器・} 近井 駿介・原田 怜於・松井 彩桜

USHIGAKI Yuya, KUBO Kaoru, SAKAMOTO Ritsuki, SEKINE Taiki, CHIKAI Shunsuke, HARADA Reo and MATSUI Sakura

\author{
（2020年 5 月 25 日受付 2020 年 9 月 7 日受理）
}

アクアラインの通行料引下げの結果，高速バスによる東京都心部や川崎・横浜方面への通勤者が増加し，その中 にはパーク\&ライドを行う人も多い. 東京大都市圈郊外としては相対的に地価も安いため, 木更津市の人口は増 加し, 中心市街地から離れた郊外住宅地がその受け皿となっている. 市や県など行政の協力・連携のもと, イオン モールなどのショッピングセンターが立地し，周辺ではチェーン店等が集積した．これにより木更津市の買物環境 と商業中心性は向上したが, 中心市街地の個人商店は厳しい状況にあり, スーパーやドラッグストアが少なく生活 必需品が購入しづらい状況にある。 その中でイオンによって無料送迎バスが運営され，高齢者の重要な移動手段と なっている．木更津市の人口分布や商業は自家用車の利用を前提とした構造となり，イオンとの関わりや更なる高 齢化が進展する中で，住民に対する買い物の機会や移動手段の確保が課題となっている.

Aqua-Line bus fares have been reduced. In the city of Kisarazu, the number of commuters to central Tokyo, Kawasaki, and Yokohama has increased, and most use highway buses. The population of Kisarazu has increased, especially in the suburbs, and large-scale shopping centers such as the AEON Mall have opened in cooperation with the government, with clusters of chain stores around them. As a result, the shopping environment of Kisarazu has improved. However, profits have declined for private shops in the city center. There are few supermarkets and drugstores, and it is difficult to purchase daily necessities. AEON operates a free shuttle bus, which is used by older people. Kisarazu's population distribution and commerce are based on the use of cars. As relations with AEON and the aging of the region progress, the ease of shopping and securing means of transportation have become an issue.

キーワード：アクアライン，通勤行動，人口動態，ショッピングセンター，木更津市 Key words: Aqua-Line, commuting behavior, population dynamics, shopping center, Kisarazu

\section{I 関心の所在と研究の目的}

1998年に開通した東京湾アクアライン（以後，ア クアラインとする) は, 開通当初の通行料が 4,000 円 と高額だったこともあり, 開通直後の 1 年間の交通量 は1 日平均約 11,000 台で, 予測值の 25,000 台を大きく 下回った。これにより千葉県や橋の麓に位置する木更 津市などでは住宅地開発や企業立地などが予定通りに は進まず, 地価が急激に下落するなど, 地域経済は停 滞した ${ }^{1)}$.
しかしアクアラインへつながる道路の整備や通行料 の低価格化によって, アクアラインの通行量は徐々に 増加した。 2009 年の 4 月に森田健作氏が千葉県知事に 就任すると, 同年 8 月から ETC を搭載する普通車の通 行料を 800 円とする社会実験を実施した。 その結果, 1 日平均の交通量が前年の 20,000 台から 29,000台へと 急増してその後も増加傾向が続き，2016年には45,000 台を記録した（図1）。これに伴い木更津市をはじめ 千葉県内では地域経済が活性化して地価も上昇 ${ }^{2)}$ する など，多方面でその影響がみられる。 


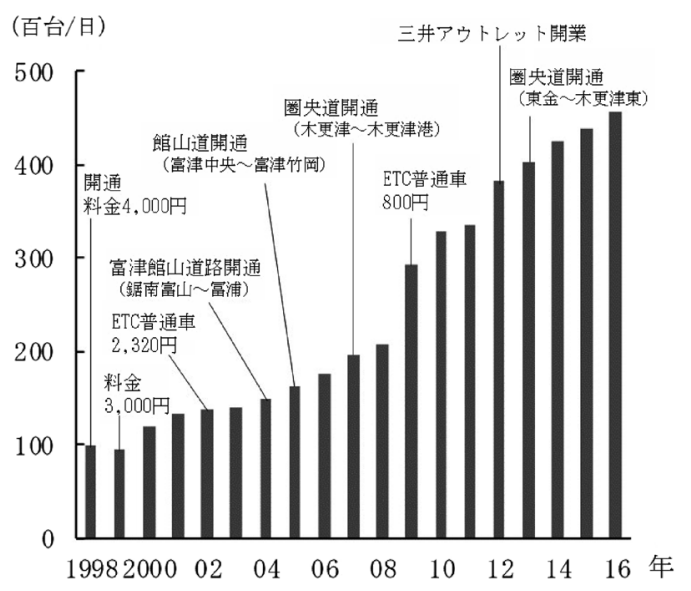

図 1 アクアラインの通行量の推移と交通政策

Fig. 1 Aqua-Line traffic volume and transportation policy (千葉県の資料により作成)

架橋が与えた地域への影響として, 磯部 (1985) は，当時建設中であった瀬戸大橋の開通に伴う倉敷市 への影響について，建設工事の受発注，漁獲量，鉄道 利用による時間の短縮，交通渋滞，瀬戸大橋の利用 料, 大型店の出店や地元商店街の動向, 工業立地や観 光客の動向などから分析した。また五味（1984）は, 石川県能登島町における能登島大橋架橋に伴う地域へ の影響について，交通の時間・費用や安全性，人口動 態, 就業機会, 観光業などから分析した.

このほかにも, 系統地理学的な関心に基づく研究と して, 杉村（1991）は, 商業地理学的な関心から, 瀬 戸大橋の四国側の着岸地である坂出の中心商業地を対 象に, 架橋によりその商業基盤が弱体化していること を示した. 川久保（1996）は，流通地理学的な関心か ら，瀬戸大橋開通に伴う中四国地方の物流の変化につ いて，岡山県において卸売業の立地や対四国物流が活 発化していることを示した，藤塚（2000）は，本州四 国間の架橋が高知市中心市街地の人口動態に与える影 響について, 交通網の改善により山陽や四国への転出 が増加するとともに, 山陽への大学進学者が卒業・就 職により高知市中心市街地へ還流移動したことを示し た. 駒木（2010）は，徳島都市圈における大型店の立 地展開とその地域的影響について, 明石海峡大橋の開 通が県外資本の大型店の流入と消費者の県外流出の一 因になったことを示した.

そのほか，主に沖縄県内の島嶼への架橋が観光およ び住民の意識や生活に与える影響を考察した研究（前

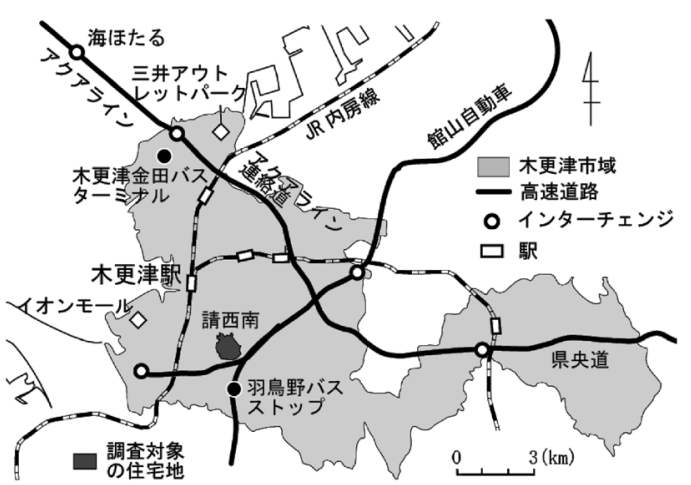

図2 研究対象地域の概要

Fig. 2 Study area

畑 2011；堀本 2011, 2012, 2017）や，広島県福山市鞆の 浦における埋立て架橋計画に伴う景観問題に対する住 民の活動や意識を考察した研究（鈴木ほか 2008; 鈴木 2014）がある.

このように地理学においては, 磯部や五味のほか は, 特定の視点から架橋の影響を考察した系統地理学 的な研究が多く蓄積されてきた. しかしこれらの成果 が示す通り, 架橋は居住人口，通勤通学行動，企業立 地, 流通 - 物流, 大型店の立地, 商店街, 観光, 景 観，住民生活等，さまざまな側面へ影響をもたらすと ともに，これらの要素は相互に関連する場合がある. 特定の現象について詳細に分析する系統地理学的な研 究にも大きな意義があるが, 地理学における地域研究 は，地域を構成するさまざまな要素を複合的に分析 し，地域的な特徵や問題を考察するのが，重要な役割 の一つといえる。

そこで本研究では, アクアラインの開通によって大 きな影響を受けている千葉県木更津市を対象に, 高速バ スや送迎バスおよび自家用車の利用といった交通的側 面, 居住人口や通勤動向といった人口的側面，ショッ ピングセンター（以下，SCとする）や商店街，消費 者行動といった商業的側面から, 架橋後の地理的特徵 や地域構造を明らかにするとともに，これにより抱え ている地域的課題について考察する。 その際，東京大 都市圈と木更津の都市内部という二つの空間スケール から考察することとする。 なお，現地調査は基本的に は2018年10月3日(水) から6日（土）にかけて実施し た。

研究対象地域の概要を図 2 に示す。アクアラインの 
着岸地である木更津市では, アクアラインやそれに向 かう連絡道として館山自動車道や県央道が整備される など，高速道路網が整備されている，市内には木更津 駅東口・西口のほか, 金田や羽鳥野にバスターミナル やバスストップがあり，高速バス交通のための環境整 備も進んでいる。自動車交通のための整備が進む中, 国内のSCとしては有数の規模を誇るイオンモール木 更津や三井アウトレットパーク木更津が立地してい る.

\section{II 木更津市の人口動態と通勤行動の変化}

1. 東京大都市圈の人口動態

1）居住人口の増減

木更津市の地理的な位置づけを把握するために，ま ずは東京大都市圈の人口動態についてみる. 図 3 は, 南関東の市区町村における 2000 年から 2015 年にかけて の人口増減率の変化を示している。主に 2000 年代には 居住人口が東京の都心部で増加するいわゆる「都心回 帰」が生じており（矢部 2003; 宮澤・阿部 2005），この 間でも東京都中央区 $(+94.7 \%)$, 千代田区 $(+62.1 \%)$, 港区 $(+52.6 \%)$, 江東区 $(+32.2 \%)$, 文京区 $(+24.8 \%)$ といった都心に近い区部で高い值がみられる。一方, 千代田区から $40 \mathrm{~km}$ 圈付近の地帯をみると, 江崎 (2006) が展望したように増加・減少する地域がともにみられ

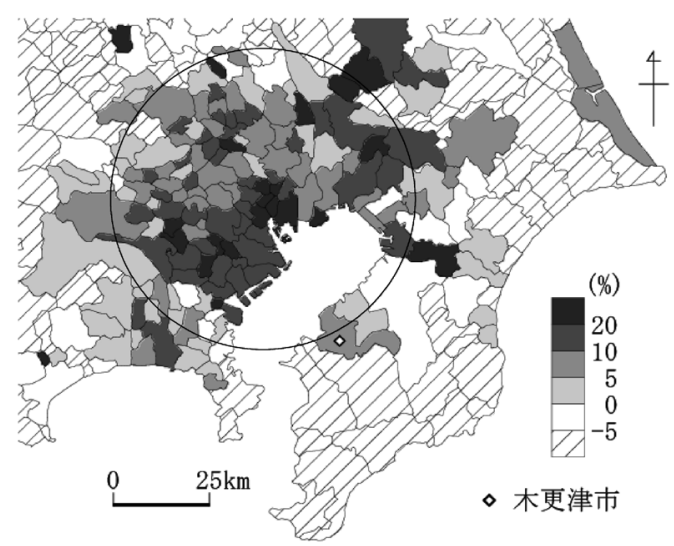

図3 東京大都市圈における人口増減率の変化（20002015 年)

Fig. 3 Population changes in the Tokyo metropolitan area, 2000-2015

図中の円は，東京都千代田区から $40 \mathrm{~km}$ の範囲を意味する. (国勢調査により作成)
地域差が生じている。この中で $5 \%$ 以上の増加率を示 す地域は千葉県木更津市 $(+9.3 \%)$, 千葉市中央区 $(+20.0 \%)$, 水海道市 $(+8.1 \%)$, 印西市 $(+16.8 \%)$, 茨城県つくばみらい市 $(+21.2 \%)$, 埼玉県白岡市 $(+9.7 \%)$, 川越市 $(+6.0 \%)$, 東京都八王子市 $(+7.7 \%)$, 町田市 $(+14.5 \%)$ ，神奈川県大和市 $(+9.5 \%)$, 横浜 市戸塚区 $(9.7 \%)$ である。一方で 5\% 以上の減少率を示 す地域は, 千葉県富津市 $(-13.7 \%)$, 君津市 $(-6.6 \%)$, 茨城県取手市 $(-8.1 \%)$, 常総市 $(-7.0 \%)$, 坂東市 $(-7.8 \%)$, 埼玉県川島町 $(-10.9 \%)$, 狭山市 $(-5.6 \%)$ である。このように郊外地帯では居住人口の増減の傾 向が異なるため, その増減が著しい地域には, その地 域特有の背景があると考えられる。

2）通勤行動の変化

木更津市における居住人口増加の背景を把握するた めに，東京区部への通勤者の動向をみる，図4は，南 関東の市区町村における 15 歳以上自宅外就業者のう ち，東京区部へ通勤する就業者の割合を示している。 東京区部から郊外に向かって同心円状に值が低くなり, 木更津市 $(5.4 \%)$ は，東京区部から東京湾に沿って連 なる $5 \%$ 以上通勤圈の最外縁部に位置している．同様 の計算と作図を 2000 年において行うと木更津市は $3.5 \%$ であり，東京区部への $5 \%$ 以上通勤圈からは外れてい る ${ }^{3)}$. 千代田区から $40 \mathrm{~km}$ 圈にかかる地域の中で, こ

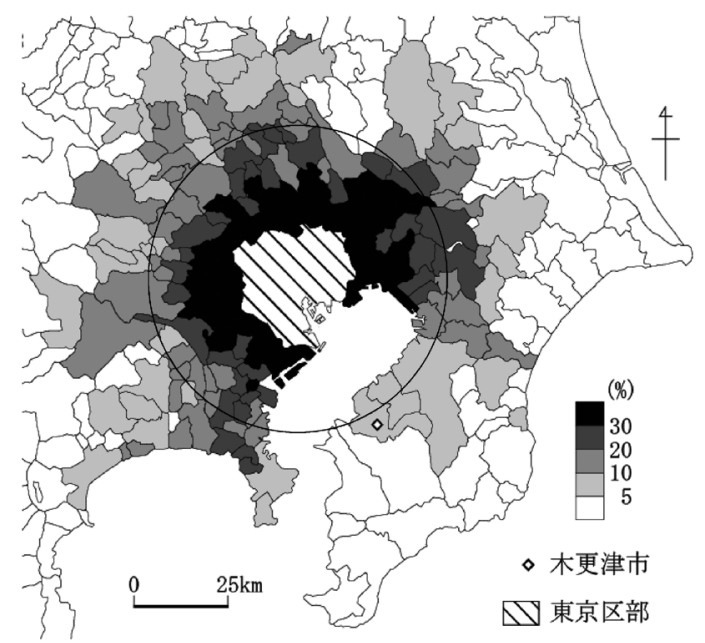

図4 東京区部の通勤圈（2015 年）

Fig. 4 Commuting area in Tokyo ward, 2015 各市区町村の 15 歳以上自宅外就業者に対する区部就業者の 割合を示す．図中の円は，東京都千代田区から $40 \mathrm{~km}$ の範囲 を意味する。

（国勢調查により作成） 
の間に $5 \%$ 圈外から圈内へ入った地域は木更津市のみ であり ${ }^{4)}$ ，この間の通勤行動において木更津市と東京 区部とのつながりが強化されたといえる.

東京大都市圈郊外居住者の区部への通勤動向につい て，谷（2002）は1990年代における20４0 km圈内の 地域を対象に，谷（2005）は同時期の埼玉県上尾市を 対象に，それぞれ区部への通勤者が減少傾向にあるこ とを示した。2000年から 2015 年における東京都に隣 接する 4 県の区部通勤者の動向を示した表 1 をみると, この間に区部への通勤者数は埼玉県で増加，千葉県で 減少が顕著である．ただしこの間は 15 歳以上就業者 の減少が著しいため, 区部通勤率はいずれも上昇して いる.このように 2000 年以降の郊外地域は, 谷が示し た1990年代の傾向とはやや異なる動向を示すが，木 更津市はその中でも特に東京とのつながりを強めた地 域といえる。

\section{2. 木更津市の人口動態}

東京大都市圈郊外の中でも，人口増加や東京区部へ の通勤者割合の上昇傾向が顕著にみられる木更津市の 人口動態についてみる。図 5 は, 1990年から 2015 年に かけての木更津市における年齢 3 区分別の人口推移を 示している. 1990年から 2005 年にかけて人口は緩や かに減少したが，それ以降は増加に転じており，2005 年から 2015 年にかけては 11,042 人増加している. 同 時に 15 歳未満人口もわずかながら上昇傾向にあるが, 生産年齢人口は基本的に減少傾向にある。6 歳以上 人口の増加が顕著であり，2005年から 2015 年にかけ ては 11,317 人増加し，この間の人口増加分を上回る. 65 歳以上人口割合は 2005 年の $19.1 \%$ から 2015 年には $25.9 \%$ となり，いわゆる超高齢社会となっている。

表 1 東京都隣接 4県における東京区部への通勤者数 の変化（2000-2015年）

Table 1 Changes in the number of commuters to Tokyo from four adjacent prefectures, 2000-2015

\begin{tabular}{lccc}
\hline & $\begin{array}{c}15 \text { 歳以上就業者 } \\
(人)\end{array}$ & $\begin{array}{c}\text { 東京区部への通勤者 } \\
(人)\end{array}$ & $\begin{array}{c}\text { 区部通勤率 } \\
(\%)\end{array}$ \\
\hline 埼玉県 & $-520,180$ & $+28,132$ & +4.53 \\
千葉県 & $-444,906$ & $-90,417$ & +0.77 \\
神奈川県 & $-561,987$ & $-4,693$ & +2.87 \\
山梨県 & $-119,886$ & +167 & +0.24 \\
\hline
\end{tabular}

(国勢調査により作成)
木更津市において人口が増加へ転じた 2005 年から 2015 年にかけての年齢 5 歳階級別人口数の変化を示し た図 6 をみると, 図 5 と同様に 65 歳以上人口の増加が 顕著であるが，生産年齢人口の中でも 35 歳から 49 歳 の階級は増加している。コーホートの視点からみると, 2005 年において 20 歳から 54 歳の間の各年代は, 10 年 後の 2015 年にかけて人口を増加させており，特に2005 年において 20 歳から 39 歳であった若い年代で増加が 顕著である。この年齢層は，大学・短大卒業後の就職 や，結婚・出産に伴い居住地選択を迫られる機会を有 する世代であり，木更津市がそれらの人々から受け入 れられていることが伺える。15歳未満人口もわずか ながら増加している。ただし，これらの比較的若い世

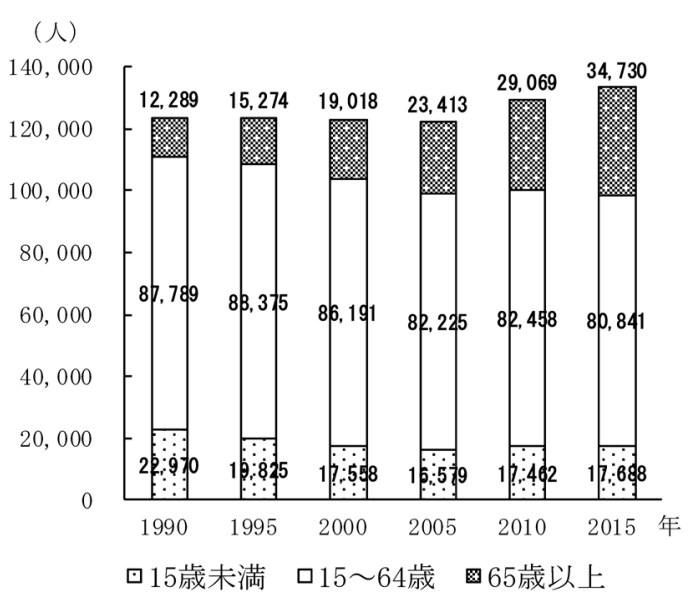

図 5 木更津市における人口推移

Fig. 5 Population changes in Kisarazu (国勢調査により作成)

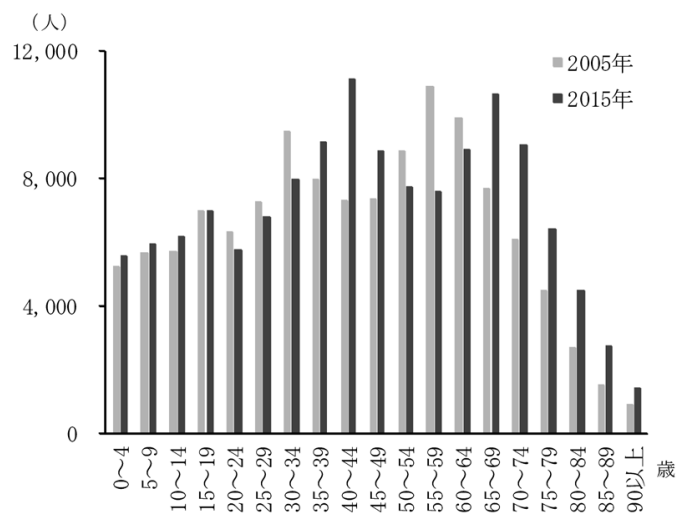

図 6 木更津市における 5 歳階級別人口数の変化 Fig. 6 Population changes by age-group in Kisarazu （国勢調查により作成） 
E-journal GEO 2020 Vol. 15(2)

表 2 木更津市における 15 歳以上就業者の通勤先の推移

Table 2 Changes in commuting destinations for workers aged 15 and older in Kisarazu

(単位：人)

\begin{tabular}{lrrrrrrr}
\hline & 1990 年 & 1995年 & 2000年 & 2005 年 & 2010 年 & 2015年 & $2005-15$ 年 \\
\hline 15歳以上就業者 & 61,511 & 63,217 & 61,106 & 58,482 & 60,940 & 63,757 & 5,275 \\
\hline 木更津市内 & 34,340 & 34,662 & 33,841 & 31,360 & 31,308 & 34,495 & 3,135 \\
千葉県 (木更津市以外) & 23,960 & 25,117 & 23,776 & 23,559 & 23,614 & 24,034 & 475 \\
茨城県 & 28 & 34 & 35 & 39 & 28 & 71 & 32 \\
埼玉県 & 60 & 77 & 55 & 65 & 78 & 80 & 15 \\
東京都 & 2,707 & 2,782 & 2,765 & 2,776 & 3,272 & 3,722 & 946 \\
神奈川県 & 381 & 446 & 581 & 627 & 773 & 910 & 283 \\
\hline
\end{tabular}

(国勢調查により作成)

代も，時が経過すれば高齢者となるため，木更津市で は今後さらに高齢者が増加するとも考えられる。

\section{3. 木更津市就業者の通勤先}

次に木更津市における 15 歳以上就業者の都道府県 別の通勤先の推移を示した表 2 をると，2005年から 2015 年にかけて，木更津市では市外での 15 歳以上就 業者が 2,140 人増加する中で, その約半数が東京都 （+946人）や神奈川県（+283人）への通勤者である ことが分かる. その増加時期をみると, アクアライン 着岸地である神奈川県では, 1990 年以降増加傾向にあ り，2005年以降はそれがより顕著である．東京都では， 2005 年まではほぼ横ばいだが，これ以降は急激に増加 している. 木更津市内就業者の増加分が $+3,135$ 人と 多いものの, 市外就業者では東京都と神奈川県の増加 分が6割弱であり，大きな割合を占めている.

木更津市における2005年から 2015 年にかけての 15 歳以上就業者の通勤先の変化を示した図 7 をると, 千葉県千葉市や市原市をはじめ, 船橋市・浦安市・東 京都江戸川区といった東京湾岸に位置する地域で減少 し, 中でも県庁所在地の千葉市は -523 人と減少数は 最大である。これは東京湾岸を通る総武線快速等の鉄 道を使った通勤者が減少しているためと考えられる。 これに対し，木更津市に近接する千葉県袖ヶ浦市・君 津市・富津市への通勤者の増加が顕著であるとともに, 東京都大田区（+408人）や川崎市川崎区（+129人） といったアクアラインの着岸地付近から, 東京都千代 田区 $(+57$ 人 $)$, 港区 $(+58$ 人 $)$, 新宿区 $(+57$ 人), 品川区 $(+79$ 人 $)$, 渋谷区 $(+61$ 人 $)$, 江東区 $(+73$ 人 $)$ といった東京都心に近い区にかけて増加がみられる.

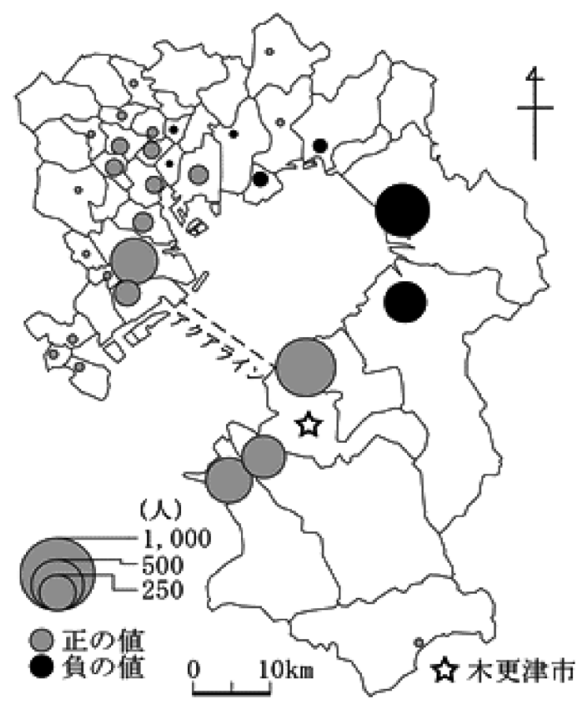

図7 木更津市就業者の通勤先の変化（2005-2015 年）

Fig. 7 Changes in commuting destinations of Kisarazu workers, 2005-2015

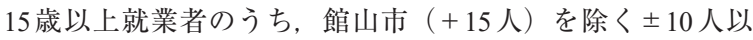
上の市区町村を掲載した。

（国勢調查により作成）

都心から $40 \mathrm{~km}$ 圈に位置する木更津市は東京大都市圈 の超郊外と位置づけることもできる，超郊外は郊外核 などの都市圈周辺と通勤などで強く結ばれるといわれ ているが（石川 2008），東京都心部や木更津市とは別 のセクターに位置する大田区・川崎区への通勤者の増 加，および東京大都市圈の郊外核の一つである千葉市 への通勤者の減少は，大都市圈の超郊外地域の動向と しては特殊な事例といえ，いずれもアクアラインが開 通し東京湾をショートカットできるようになったこと が背景にあると考えられる。

次いで 2015 年の木更津市における 15 歳以上就業者 の通勤先を示した図 8 をみると，木更津市就業者の通 


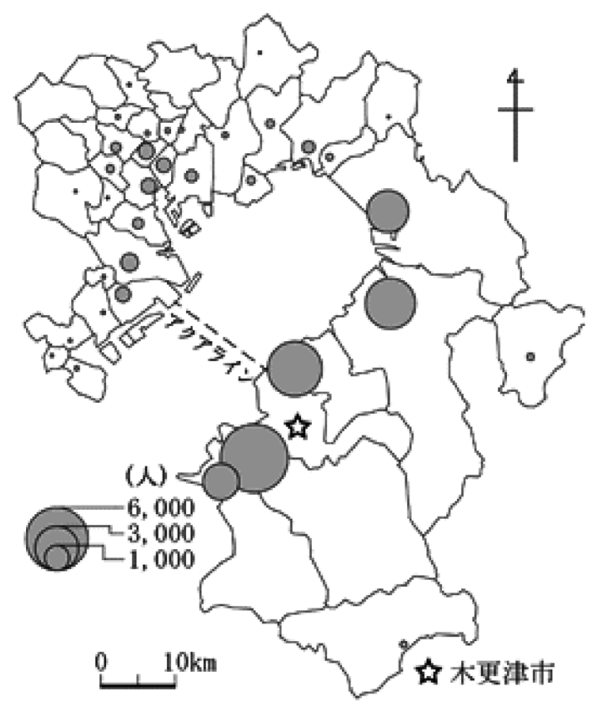

図 8 木更津市就業者の通勤先（2015 年）

Fig. 8 Kisarazu workers' commuting destinations, 2015 15 歳以上就業者のうち, 館山市 (123 人) を除く 30 人以上の 市区町村を掲載した。

（国勢調查により作成）

勤先は，11工業地帯を抱える近隣地域（市原市，袖ヶ浦 市，君津市）への通勤，(2)県庁所在地である千葉市へ の通勤 ${ }^{5)}$ ，(3)クアラインを利用した通勤へと大別で きる. (1)や(2)は以前からみられたがあ)，(3)は2005年以 降に新たにみられる傾向であり, アクアラインを使っ た東京区部や川崎方面への通勤者の増加は，木更津市 にとって大きな変化といえる.

4. 木更津市就業者の通勤手段

1）通勤手段の変化とその背景

前節でみたように，アクアラインを使った通勤者が 増加した背景を把握するために，他県へ通勤する木更 津市就業者の通勤》手段をみる。国勢調査において利 用交通手段が把握できる 2000 年と 2010 年の值を示し た表3をみると，鉄道の利用者が減少しているのに対 して, 乗合バスや勤め先のバスを利用した通勤者が増 加している。この間の他県への従業・通学者は 743 人 増加する中で，バスを利用した通勤者は646人増加し ている. 自動車のみの利用者も 122 人増加しており, これらは2009年のアクアライン通行料の低価格化の 影響と考えられる。

バスによる通勤者が増加した背景として，アクアラ イン開通以降, 着岸地付近や東京都心部へ向かう高速
表3 木更津市における他県への就業者・通学者の交 通手段

Table 3 Methods of transportation of Kisarazu workers and commuters to other prefectures

(単位：人)

\begin{tabular}{lrrr}
\hline & 2000 年 & 2010 年 & 増減 \\
\hline 他県への従業・通学者総数 & 3,489 & 4,232 & 743 \\
利用交通手段が1種類 & 1,432 & 2,085 & 653 \\
鉄道・電車 & 956 & 899 & -57 \\
乗合バス & 126 & 444 & 318 \\
勤め先・学校のバス & 11 & 211 & 200 \\
自家用車 & 294 & 416 & 122 \\
オートバイ & 4 & 17 & 13 \\
その他 & 41 & 50 & 9 \\
利用交通手段が2種類 & 1,725 & 1,580 & -145 \\
鉄道・電車及び乗合バス & 575 & 703 & 128 \\
鉄道・電車及び自家用車 & 564 & 241 & -323 \\
鉄道・電車及びオートバイ & 126 & 44 & -82 \\
鉄道・電車及び自転車 & 246 & 147 & -99 \\
その他利用交通手段が2種類 & 214 & 213 & -1 \\
利用交通手段が3種類以上 & 321 & 512 & 191 \\
不詳 & 0 & 55 & \\
\hline
\end{tabular}

15 歳以上を対象とした.

(国勢調査により作成)

バスの開設があげられる，木更津市内の停留所に停車 するアクアライン高速バス路線の一覧を示した表4を みると，アクアラインが開通した1997年には，川崎 側の着岸地に近い川崎線, 横浜線, 羽田線が開通して いる．その後に東京・品川といった東京都心方面の主 要駅へと拡大し，2007年の低価格化以降には新宿・渋 谷方面へとさらに拡大している.

木更津市内に停車する高速バス路線の便数と輸送人 員数の推移を示した図 9 をると, アクアライン開通 以降, これを経由した便数や輸送人員は急激に上昇を 続けているのに対して，これを経由しない高速バスは 横ばい傾向が続いている。 アクアライン開通以降，木 更津市内の高速バスはこれを利用した交通体系へと変 化している.

アクアラインを用いた高速バスの利用者が増加して いる背景を把握するために，高速バスと鉄道による通 勤時間と運賃を比較する。物理的距離としての木更津 駅〜東京駅間は，東京湾沿岸を通る鉄道ルートでは 約 $70 \mathrm{~km}$ であるのに対して，アクアラインを通るバス ルートでは約 $45 \mathrm{~km}$ に短縮されている. 木更津駅から 東京や川崎・横浜方面の主要駅への所用時間と運賃を 示した表 5 をると, 鉄道に対してアクアライン高速 
表4木更津市におけるアクアライン高速バス路線

Table 4 Aqua-Line highway bus line routes in Kisarazu

\begin{tabular}{|c|c|c|c|c|c|c|}
\hline 路線名 & 開始年 & $\begin{array}{l}\text { 事業者 } \\
\text { 数 }\end{array}$ & $\begin{array}{c}\text { 平日便 } \\
\text { 数 }\end{array}$ & $\begin{array}{l}\text { 休日便 } \\
\text { 数 }\end{array}$ & 木更津市の停車箇所 & 東京都・神奈川県の停車箇所 \\
\hline 木更津川崎線 & 1997 & 5 & 30 & 20 & $\begin{array}{l}\text { 木更津駅東口，木更津金田バスターミナル， } \\
\text { (海ほたる) }\end{array}$ & 浮島バスターミナル，川崎駅 \\
\hline 木更津横浜線 & 1997 & 3 & 44 & 44 & $\begin{array}{l}\text { (かずさアーク }),(\text { 矢那川ダム }), \text { 木更津駅東 } \\
\text { 口, (木更津金田バスターミナル) }\end{array}$ & 横浜駅 \\
\hline 木更津羽田線 & 1997 & 4 & 37 & 37 & 木更津駅東口, （木更津金田バスターミナル） & $\begin{array}{l}\text { 第 } 1 \text { ターミナル, 第 } 2 \text { ターミナル, 国際線 } \\
\text { ターミナル }\end{array}$ \\
\hline 鴨川東京線 & 1998 & 3 & 20 & 20 & $\begin{array}{l}\text { かずさアーク, 矢那川ダム, 暁星国際学園前, } \\
\text { 木更津総合高校前, 木更津中郷, 木更津金田 } \\
\text { バスターミナル }\end{array}$ & $\begin{array}{l}\text { 東京駅, (浜松町バスターミナル), （東京 } \\
\text { タワー） }\end{array}$ \\
\hline 君津東京線 & 2000 & 2 & 54 & 47 & $\begin{array}{l}\text { 羽鳥野バスストップ, 木更津金田バスターミ } \\
\text { ナル }\end{array}$ & $\begin{array}{l}\text { 東京駅, （浜松町バスターミナル）,（東雲 } \\
\text { 車庫） }\end{array}$ \\
\hline 木更津品川線 & 2002 & 3 & 50 & 32 & 木更津駅東口, （木更津金田バスターミナル） & 品川駅 \\
\hline 君津羽田線 & 2002 & 2 & 16 & 16 & 羽鳥野バスストップ & $\begin{array}{l}\text { 第 } 1 \text { ターミナル, 第 } 2 \text { ターミナル, 国際線 } \\
\text { ターミナル }\end{array}$ \\
\hline 木更津東京線 & 2003 & 2 & 33 & 33 & $\begin{array}{l}\text { (高速桜井), (潮見), (イオンモール木更津), } \\
\text { 木更津駅西口, 木更津金田バスターミナル }\end{array}$ & 東京駅, （東雲車庫） \\
\hline 勝浦東京線 & 2007 & 3 & 6 & 6 & 木更津金田バスターミナル & 東京駅, 浜松町バスターミナル \\
\hline 木更津新宿線 & 2008 & 2 & 36 & 36 & 木更津駅西口，（木更津金田バスターミナル） & （バスタ新宿），（新宿駅） \\
\hline 館山新宿線 & 2014 & 2 & 11 & 11 & 羽鳥野バスストップ & バス夕新宿 \\
\hline 君津新宿線 & 2017 & 2 & 8 & 8 & 羽鳥野バスストップ & バス夕新宿 \\
\hline 木更津渋谷線 & 2018 & 2 & 18 & 16 & 木更津駅西口 & 渋谷マークシティ \\
\hline 鴨川渋谷線 & 2018 & 2 & 4 & 4 & $\begin{array}{l}\text { かずさアーク, 矢那川ダム, 暁星国際学園前, } \\
\text { 木更津総合高校前, 木更津中郷, 木更津金田 } \\
\text { バスターミナル }\end{array}$ & 渋谷マークシティ \\
\hline
\end{tabular}

2018年 10 月時点の路線を掲載した。（）は一部路線のみ停車する箇所を意味する.

(木更津市統計書, 日東交通の資料, 小湊鐵道の資料により作成)

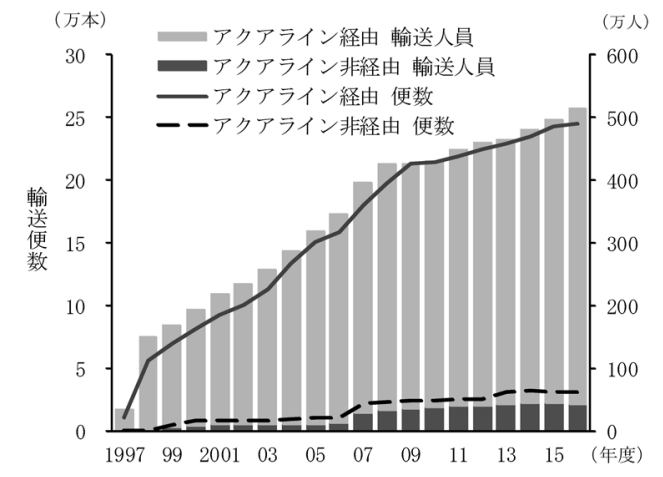

図9 木更津市における高速バス路線の便数と輸送人 員の推移

Fig. 9 Changes in the number of highway bus routes and transport personnel in Kisarazu 木更津市内に停車する高速バスを対象とした. (木更津市統計書により作成)

バスは全ての駅間で所用時間が短縮されており, 羽田 空港は 3 分の 1 以下, 横浜駅は 2 分の 1 以下となってい る. 運賃では，高速バス利用の方が，羽田空港では 580 円，横浜駅では390円安いが，その他の駅では差 は小さく，東京駅・新宿駅・渋谷駅では高速バスの方 が30〜60円程高い. 運賃の差は評価が難しいが, 所
表5 アクアライン高速バスと鉄道の所要時間・運賃 の比較

Table 5 Comparison of travel times and fares for the Aqua-Line Express Bus and Train

\begin{tabular}{lrrllc}
\hline \multirow{2}{*}{ 行先 } & \multicolumn{2}{c}{ 鉄道 } & & \multicolumn{2}{c}{ アクアライン高速バス } \\
\cline { 2 - 3 } \cline { 5 - 6 } & 時間 & 運賃 & & 時間 & 運賃 \\
\hline 東京駅 & 88 分 & 1,320 円 & & 59 分 & 1,350 円 \\
羽田空港 & 134 分 & 1,810 円 & & 42 分 & 1,230 円 \\
品川駅 & 100 分 & 1,490 円 & & 63 分 & 1,350 円 \\
新宿駅 & 111 分 & 1,490 円 & & 75 分 & 1,550 円 \\
渋谷駅 & 118 分 & 1,490 円 & & 85 分 & 1,550 円 \\
川崎駅 & 121 分 & 1,660 円 & & 69 分 & 1,440 円 \\
横浜駅 & 122 分 & 1,940 円 & & 58 分 & 1,550 円 \\
\hline
\end{tabular}

木更津駅からの時間と運賃を掲載する。鉄道の所要時間は 「えきねっと 乗換・運賃案内」の平均所要時間検索機能を 用いた。

（「えきねっと 乗換・運賃案内」，木更津市パンフレット， 日東交通の資料, 小湊鐵道の資料により作成)

要時間の面で大幅な短縮が見込まれ，高速バス通勤の 魅力の一つといえる。また道路運送法により高速バス では着席やシートベルトの着用が義務づけられてお り，高速バスの利用者は全て座ることができ，これも 魅力の一つと考えられる. 
2）パーク\&ライドによる通勤

通勤手段として高速バスの利用が進む背景の一つと して，木更津版のパーク＆ライドともいえる通勤方法 が確立している点があげられる．アクアラインの木更 津側の着岸地には金田バスターミナルがあり（図2）, その付近には多くの駐車場が設けられている.川崎・ 東京方面への通勤者は，自家用車で自宅から金田バス ターミナル付近の駐車場へ来て駐車し, そこから高速 バスに乗車して通勤をする人が存在する．木更津金田 バスターミナル周辺の駐車場の料金・収容台数と調査 時点における利用状況を示した表 6 をみると，それら の駐車場は合わせて 945 台の収容台数があり，うち 733 台は利用中であった。

表3をみると，2010年の木更津市の 15 歳以上県外就 業者のうち,「その他利用交通手段が 2 種類」とする人 は 213 人だが，そのうち一定程度は自宅から自家用車 でバスターミナルまで向かって高速バスへ乗車し, 東 京・神奈川方面へ向かう人と考えられる。また「利用 交通手段が 3 種類以上」とする人は 512 人だが，その うち一定程度は上記に続いて高速バス下車後に鉄道で 職場の最寄り駅まで向かう人と考えられ，いずれもこ のパーク\&ライドの利用者が一定程度存在すると考え られる。表 3 からバス利用者が少なくとも 1,358 人い ることを踏まえると，2010年におけるバスによる通勤 者は相当数に及ぶと考えられ，木更津金田バスターミ ナル周辺の駐車場は, その主要な受け皿になってい る.「鉄道・電車及び自家用車」による通勤者が 323

表6 木更津金田バスターミナル付近の駐車場 Table 6 Parking lot near the Kisarazu Kaneda bus terminal

\begin{tabular}{|c|c|c|c|c|}
\hline \multirow{2}{*}{ 駐車場 } & \multicolumn{2}{|c|}{ 料金（円） } & \multirow{2}{*}{$\begin{array}{l}\text { 収容 } \\
\text { 台数 }\end{array}$} & \multirow{2}{*}{$\begin{array}{l}\text { 駐車 } \\
\text { 台数 }\end{array}$} \\
\hline & 1 日 & 1 か月 & & \\
\hline 木更津金田第一※ & 500 & 4,000 & 290 & 265 \\
\hline 木更津金田第二※ & 400 & 3,000 & 108 & 38 \\
\hline アクアパーキング P1 & 300 & 2,500 & \multirow{2}{*}{56} & \multirow{2}{*}{38} \\
\hline アクアパーキング P2 & 300 & 3,000 & & \\
\hline アクアパーキング P3 & 350 & 3,500 & 203 & 186 \\
\hline アクアパーキング P4 & 300 & 2,500 & 21 & 15 \\
\hline かもめ有料駐車場 & 300 & なし & 100 & 48 \\
\hline ナビパーク木更津瓜倉第 1 & 300 & なし & 63 & 62 \\
\hline 共栄駐車場 & 400 & 4,000 & 104 & 81 \\
\hline
\end{tabular}

※は市営の駐車場を意味する。駐車台数は, 2018年 10 月 5 日 10 時 30 分ころに実施した調査時点の值である.

(現地調査により作成)
人減少しているのも，この自家用車とバスによるパー ク\&ライドを活用した通勤者の増加の影響が大きいと 考えられる。

木更津金田バスターミナルにおいて，平日の高速バ スの利用実態を示した表7をみると，出勤時間帯に当 たる 7 時台は 1 ～分間隔と高頻度で発車している。 そ れでも7時37分発を除く全てにおいて積み残しが発生 しており，満車となっている．ただし積み残しの人数 以上に, 次のバスで乗車する人数が多いため, 乗車の ために待つのはせいぜいバス 1 本分程度である。バス の本数が多くて待ち時間が短く利用しやすい状況であ ることが，高速バスによる通勤が増えている背景の一

表7 平日における木更津金田バスターミナルの利用 Table 7 Kisarazu Kaneda bus terminal use on weekdays (単位：人)

\begin{tabular}{|c|c|c|c|c|}
\hline 予定発車時間 & 行先 & 乗車待ち & 乗車 & 積み残し \\
\hline \multicolumn{5}{|l|}{ 7時台 } \\
\hline 7:02 & 浜松町 & $12(4)$ & 6 & 6 \\
\hline 7:04 & 東雲車庫 & $8(1)$ & 7 & 1 \\
\hline 7:07 & 浜松町 & $8(2)$ & 6 & 2 \\
\hline $7: 12$ & 東雲車庫 & $22(11)$ & 16 & 6 \\
\hline $7: 17$ & 東京駅 & $34(18)$ & 21 & 13 \\
\hline $7: 22$ & 東雲車庫 & $39(12)$ & 13 & 26 \\
\hline 7:08 & 東京タワー & $39(12)$ & 30 & 9 \\
\hline $7: 24$ & 浜松町 & $18(7)$ & 12 & 6 \\
\hline $7: 27$ & 浜松町 & $27(9)$ & 10 & 17 \\
\hline $7: 30$ & 東雲車庫 & $36(13)$ & 15 & 21 \\
\hline $7: 32$ & 東京駅 & $25(10)$ & 23 & 2 \\
\hline $7: 34$ & 東雲車庫 & $4(0)$ & 2 & 2 \\
\hline $7: 37$ & 東京駅 & $8(2)$ & 8 & 0 \\
\hline $7: 42$ & 東京駅 & $28(12)$ & 26 & 2 \\
\hline $7: 38$ & 浜松町 & $12(6)$ & 11 & 1 \\
\hline $7: 47$ & 浜松町 & $11(4)$ & 6 & 5 \\
\hline $7: 54$ & 東雲車庫 & $15(6)$ & 3 & 12 \\
\hline $7: 57$ & 東雲車庫 & $24(12)$ & 21 & 3 \\
\hline \multicolumn{5}{|l|}{12 時台 } \\
\hline $12: 02$ & 東雲車庫 & $8(1)$ & 8 & 0 \\
\hline $12: 22$ & 東雲車庫 & $9(6)$ & 9 & 0 \\
\hline $12: 29$ & 東雲車庫 & $3(1)$ & 3 & 0 \\
\hline $12: 28$ & 浜松町 & $2(0)$ & 2 & 0 \\
\hline $12: 42$ & 東雲車庫 & $3(1)$ & 3 & 0 \\
\hline \multicolumn{5}{|l|}{17 時台 } \\
\hline $17: 04$ & 東雲車庫 & $7(3)$ & 7 & 0 \\
\hline $17: 12$ & 東雲車庫 & $3(1)$ & 3 & 0 \\
\hline $17: 13$ & 浜松町 & $0(0)$ & 0 & 0 \\
\hline $17: 24$ & 浜松町 & $5(4)$ & 5 & 0 \\
\hline $17: 34$ & 東雲車庫 & $1(0)$ & 1 & 0 \\
\hline $17: 42$ & 東雲車庫 & $6(1)$ & 6 & 0 \\
\hline $17: 43$ & 浜松町 & $0(0)$ & 0 & 0 \\
\hline
\end{tabular}

（）は女性の人数を意味する。高速バスの発車順に記載し ている.

（2018年 10 月 5 日（金）に実施した現地調查により作成） 
つと考えられる。 な打昼や夕方の時間帯はバスの本数 が少なくなるものの利用者は少なく，積み残しは発生 しない，乗車待ちをしている人の性別をみると，男性 が延べ 258 人，女性が延べ 159 人であり，男性女性と もに利用している.

一般的に, 大都市圈の郊外および超郊外の住宅地は, 私鉄沿線に形成される場合が多く，通勤手段は鉄道が 大部分と考えられるが，木更津市ではアクアラインの 存在によってバス通勤が進んでいる．これも人口増加 や東京都心部への通勤者の増加といった同市の特徵を 支える特殊な条件といえる.

\section{5. 木更津市に扔ける住宅地開発と人口分布}

木更津市では，高度経済成長期以降，区画整理事業 等の都市計画に基づく住宅地開発が行われてきた．第 二次世界大戦後, 京葉工業地帯における工場誘致が促 進される中で, 1960 年に隣接する君津市へ八幡製鐵が 誘致されると, 1963 年の清見台団地の開発を皮切りに, さまざまな宅地や団地が開発された。それは2000年以 降も続き，土地区画整理事業等の大規模な再開発が実 施された地域では，町名の変更や分割・統合などの動 きがみられた。 木更津市に打いて 2005 年から 2015 年 にかけて新設された町丁と，2015年の人口密度を示し た図 10 みると,この間に新設された町丁はいずれも 木更津駅からは離れ, 高速道路のインターチェンジ付 近やそれに続く主要道路に面した場所に位置しており, 自家用車の利用を前提とした場所で宅地開発が行われ たと考えられる。

この新設町丁における2005年から 2015 年にかけて の人口増減数をみると, 12,890 人 $^{8)}$ 増加しており, こ の間の木更津市全体の増加数 11,317 人を上回るのに対 して，2005年および2015年にいずれも存在する町丁 では 1,500 人の減少となる。これより，この間に新設 された住宅地が，この間に増加した人口の主要な受け 皿になったと考えられる．2015年の木更津市の人口 分布をみても，全体として市の西部に偏ってはいるも のの, 木更津駅から $2 \mathrm{~km}$ 以上離れ, 主要道路に面し た地区に集中しており，自家用車の利用を前提とした 都市構造になっていることが分かる.

木更津市扮よび千葉県に打ける人口 1 人当たりの自 動車保有台数をみると ${ }^{9)}$, アクアライン開通前の 1995
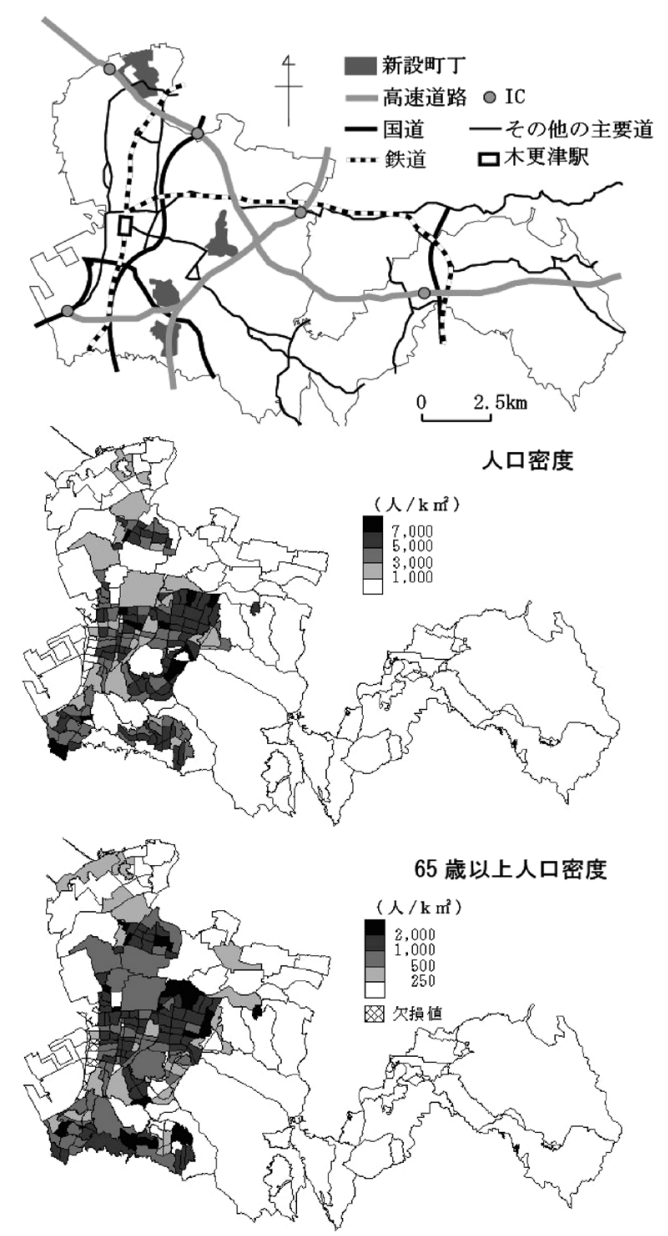

図 10 木更津市の人口密度と 65 歳以上人口密度 $(2015$ 年)

Fig. 10 General population density and population density of residents over 65 years of age in Kisarazu, 2015

（国勢調查により作成）

年では木更津市 0.52 台/人, 千葉県 0.40 台/人に対して, 2018 年には木更津市は 0.68 台/人, 千葉県は 0.50 台/人 となっている.もともと千葉県に対して木更津市の方 が 1 人当たり自動車保有台数は多いが，その後の上昇 も顕著である。このことからも，木更津市が自動車の 利用を前提とした都市構造になりつつあることが読み 取れる。

図10に示した新設町丁について, 年齢別の人口数を 表8に示す。ここでは図6でみられた傾向を踏まえ，木 更津市全体に打いて 2005年から 2015 年の間に増加し た35歳から49歳の世代を一括りとした３5４9歳で は，木更津市全体や既存町丁に対して新設町丁で $10 \%$ ほど割合が高い．同様に15歳未満でも割合が高いのに 
表 8 木更津市の新設町丁における年齢別人口割合 (2015 年)

Table 8 Kisarazu's new town population ratio by age, 2015

\begin{tabular}{|c|c|c|c|c|c|c|}
\hline & \multicolumn{2}{|c|}{ 木更津市 } & \multicolumn{2}{|c|}{ 既存町丁 } & \multicolumn{2}{|c|}{ 新設町丁 } \\
\hline & (人) & $(\%)$ & （人） & $(\%)$ & （人） & $(\%)$ \\
\hline $0 \sim 14$ 歳 & 17,688 & 13.3 & 13,733 & 11.5 & 3,955 & 28.7 \\
\hline 15～34 歳 & 27,508 & 20.6 & 23,987 & 20.1 & 3,521 & 25.6 \\
\hline 35～49歳 & 29,111 & 21.8 & 24,854 & 20.8 & 4,257 & 30.9 \\
\hline $50 \sim 64$ 歳 & 24,222 & 18.2 & 23,087 & 19.3 & 1,135 & 8.2 \\
\hline 65 歳以上 & 34,730 & 26.1 & 33,819 & 28.3 & 911 & 6.6 \\
\hline
\end{tabular}

新設町丁は2005年から 2015 年にかけて新設された町丁を, 既存町丁はそれ以外の町丁を意味する。

（国勢調查により作成）

表9 東京大都市圈郊外都市の地価公示 (2018年)

Table 9 Official land prices in suburbs of the Tokyo metropolitan area, 2018

\begin{tabular}{ccc}
\hline \multicolumn{1}{c}{ 市名 } & 都県 & 住宅地地価 $\left(\right.$ 円 $\left./ \mathrm{m}^{2}\right)$ \\
\hline 木更津市 & 千葉 & 32,400 \\
君津市 & 千葉 & 35,300 \\
市原市 & 千葉 & 44,900 \\
佐倉市 & 千葉 & 61,700 \\
四街道市 & 千葉 & 61,300 \\
印西市 & 千葉 & 38,700 \\
桶川市 & 埼玉 & 92,300 \\
福生市 & 東京 & 162,700 \\
八王子市 & 東京 & 115,800 \\
座間市 & 神奈川 & 151,900 \\
綾瀬市 & 神奈川 & 125,500 \\
\hline
\end{tabular}

千代田区より $40 \mathrm{~km}$ 圈に位置する主な市について, 自治体内 の全地点の合計額を地点数で除した值を示す.

（土地情報センターの資料により作成）

対して，65歳以上人口割合は $20 \%$ ほど低い。このよう に新設された新興住宅地においては，比較的若い家族 世帯が入居する傾向がみられる，新設町丁は自家用車 の利用を前提とした場所に位置するため，将来的に 徐々に自家用車の運転が困難な年齢になると, 居住者 の日常的な移動手段が問題となる可能性が高い ${ }^{10)}$.

\section{6. 東京大都市圈郊外地域の住宅価格}

木更津市で人口や東京都心部等への通勤者が増加し ている背景として, 他の東京大都市圈郊外地域に比べ て相対的に住宅価格や家賃が安いことがあげられる. 表 9 は，東京都千代田区から半径 $40 \mathrm{~km}$ 圈に位置する 主な市の住宅地地価の平均值を示している.これによ ると, 木更津市の地価は他地域の価格と比べて安く, 青梅線沿線に位置する福生市に対しては $19.9 \%$ の值で

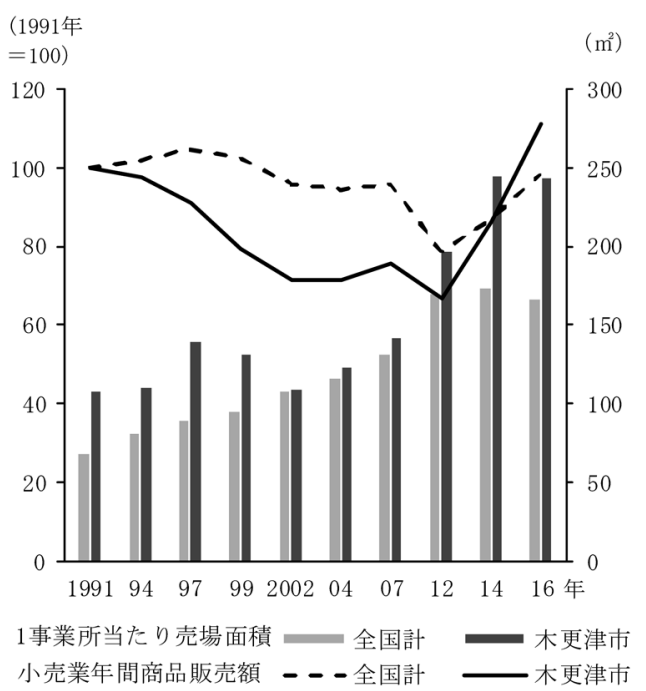

図 11 木更津市における小売業の販売額と売場面積 の変化

Fig. 11 Changes in retail sales and sales floor area in Kisarazu

（商業統計表により作成）

ある．Iで述べたように，近年の木更津市は地価が上 昇しているとはいえ，依然として低い水準にある，実 際の住宅価格や賃貸料は場所や築年数などによって異 なるが, 市の平均值としては大きな差があり，実際の 住宅地価格にもそれが反映されると考えられる ${ }^{11)}$.

\section{III アクアライン開通後の商業空間}

1. 木更津市における大型店の立地と商業の変化

1）大型店の立地傾向

IIでは, アクアラインの開通とその利用が，木更津 市の人口や通勤行動に影響を与えたことをみたが，III ではその商業への影響についてみる。全国的に大型店 の立地が進んだ 1991年から 2016年にかけての小売販売 額と小売業 1 事業所当たりの売場面積の推移を示した 図11をみると, 1991年を 100 とした場合の小売販売額 は，木更津市は 1991 年から 2012 年にかけて減少が続 き，全国と比べても著しく低い值で推移している．特 に減少が顕著な 1994年から 2002 年にかけては, アクア ラインが開通したものの利用者が予想を大幅に下回っ た時期に当たり，これにより商業面で中心性が低下し たことが伺える。一方，三井アウトレットパークが開 業した 2012 年, イオンモール木更津が開業した2014年 
以降は急激に上昇しており，2016年の小売販売額は 1991 年比で $111 \%$ と, アクアライン開通以前を上回る. 小売業 1 事業所当たりの売場面積をみると, 1991年 から木更津市は全国と比べて売場面積が大きく，アク アラインが開通する1997年に向けて上昇するが，その 後2002年に向けて縮小している.これは木更津駅西口 の木更津そごうが2000年に閉店し，2004年にそのビ ルがアクア木更津としてリニューアルする間の時期に あたるためと考えられる。一方，2007年から 2014 年 にかけては急激に上昇しており，その間の上昇幅は全 国の值を大きく上回る。このように木更津市では，ア クアラインが開通したものの料金が高く利用者が少な い時期には小売の販売額や売場面積が減少・縮小した が, その利用者の増加に伴って小売業の大規模化が進 み販売額も上昇している.

木更津市における大規模小売店舗の分布を示した図 12 をみと, アクアラインの木更津側着岸地付近にお いて，三井アウトレットパークを核として，比較的規 模の大きな小売店の集積がみられる。同様に木更津駅 から南西方面へ $2.3 \mathrm{~km}$ ほどに位置するイオンモール木 更津の規模の大きさも際立っている．木更津駅の西口 には，かつての木更津そごうの位置にスパークルシ ティ木更津がある．木更津駅から北東へ約 $1 \mathrm{~km}$ に位

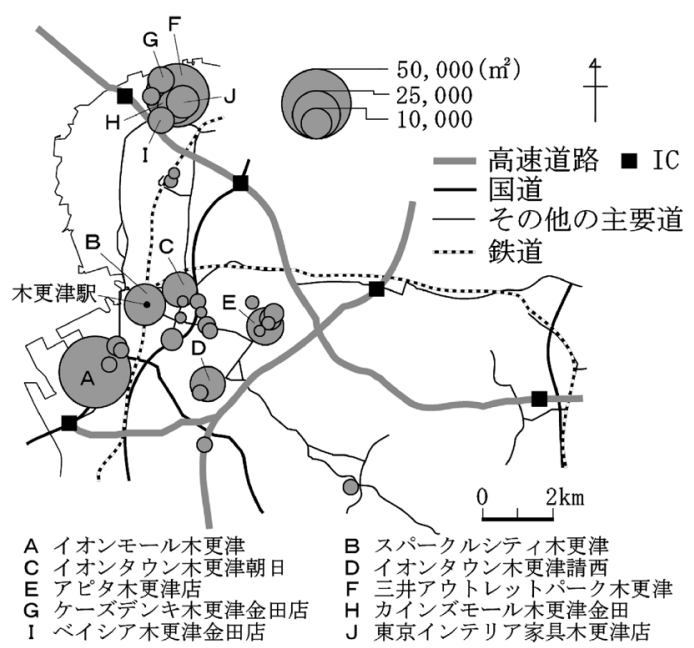

図 12 木更津市における大規模小売店舗の分布 (2018 年)

Fig. 12 Distribution of large-scale retail outlets in Kisarazu, 2018

店舗面積 $1,000 \mathrm{~m}^{2}$ 以上の店舗を掲載する.

(木更津市中心市街地活性化基本計画により作成)
置するのがイオンタウン木更津朝日である。そのほか で $10,000 \mathrm{~m}^{2}$ を超える店舗は，木更津駅から南東へ $2.8 \mathrm{~km}$ ほどに位置するイオンタウン木更津請西や，木更津 駅から東へ $3.3 \mathrm{~km}$ ぼに位置するアピタ木更津店と, いずれも木更津駅からやや離れた場所に位置してい る. 全体的な分布傾向としては，いずれもインター チェンジや国道，その他の主要道路沿いに立地してお り，また三井アウトレットパーク木更津，イオンモー ル木更津，アピタ木更津店が核となって他の大型店が 集積する傾向がみられる。

2）三井アウトレットパーク木更津の立地とその周 辺地域への影響

三井アウトレットパーク木更津は2012年4月に開業 し，2018年10月 26 日には第3期のグランドオープン を迎え, 店舗数は 308 店, 店舗面積は $42,753 \mathrm{~m}^{2}$ とな り，アウトレット施設としては国内最大規模を誇る. 木更津市によって地区計画が行われ，この施設を含む金 田東地区は都市再生機構（UR）, 金田西地区は千葉県に よって土地区画整理事業が施行された。この国内最大 規模の商業施設の周辺地域には, 図 12 にられる大規 模小売店舗としてカインズモール $\left(12,797 \mathrm{~m}^{2}\right)$, 東京 インテリア家具 $\left(11,650 \mathrm{~m}^{2}\right)$, ケーズデンキ $\left(7,747 \mathrm{~m}^{2}\right)$, ベイシア $\left(7,265 \mathrm{~m}^{2}\right)$ のほか, 多くのチェーン店が集 積している.

三井アウトレットパーク木更津における業種別店舗 数を示した表 10 をると,アウトレット施設であるた め男子服・婦人服などを中心に服飾関係の業種が大部 分を占めている。一方，このアウトレット施設と高速 道路の間のおよそ半径 $1 \mathrm{~km}$ に店舗が集積しており，そ

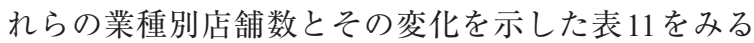
と, 自動車小売業, 家具 - 建具 - 畳小売業, 宿泊業, 洗濯・理容・美容・浴場業など，アウトレット施設に は少ない業種が数多く立地している。これらの店舗は 国内最大規模のアウトレット施設へ訪れる顧客を主な ターゲットとしていると考えられ，アウトレット施設 とは業種の差別化が図られている。アウトレットの開 業以前にあたる 2010 年の店舗数は，14店舗とわずか であった。この一帯では，国内最大規模を誇る三井ア ウトレットパーク木更津の立地に伴って別業種の店舗 の集積が進んだことで，多様な業種からなる商業集積 が形成されたといえる。 
表 10 三井アウトレットパーク木更津における業種 別店舗数（2018年）

Table 10 Number of retail outlets by industry in Mitsui Outlet Park Kisarazu, 2018

\begin{tabular}{|c|c|}
\hline 業種 & 店数 \\
\hline 吳服·服地・寝具小売業 & 1 \\
\hline 男子服小売業 & 68 \\
\hline 婦人服小売業 & 86 \\
\hline 靴·履物小売業 & 9 \\
\hline その他の織物・衣服・身の回り品小売業 & 35 \\
\hline 野菜・果実小売業 & 3 \\
\hline その他の飲食料品小売業 & 2 \\
\hline 自動車小売業 & 1 \\
\hline 機械器具小売業 & 1 \\
\hline 医療・化粧品小売業 & 2 \\
\hline スポーツ用品・玩具・娛楽用品小売業 & 23 \\
\hline 写真機・時計・眼鏡小売業 & 9 \\
\hline 飲食店 & 22 \\
\hline 持ち帰り・配達飲食サービス業 & 6 \\
\hline 合計 & 268 \\
\hline
\end{tabular}

(現地調査により作成)

表11 三井アウトレットパーク木更津の周辺に立地 する業種別店舗数とその変化

Table 11 Change in number of retail outlets by industry located around Mitsui Outlet Park Kisarazu

\begin{tabular}{|c|c|c|}
\hline 業種 & 2010年 & 2018 年 \\
\hline 百貨店・総合スーパー & 0 & 1 \\
\hline 婦人・子供服小売業 & 0 & 1 \\
\hline 靴·履物小売業 & 0 & 1 \\
\hline 各種食料品小売業 & 4 & 2 \\
\hline 鮮魚小売業 & 2 & 1 \\
\hline その他の飲食料品小売業 & 0 & 2 \\
\hline 自動車小売業 & 0 & 4 \\
\hline 自転車小売業 & 1 & 1 \\
\hline 機械器具小売業 & 0 & 1 \\
\hline 家具·建具・畳小売業 & 1 & 5 \\
\hline 燃料小売業 & 1 & 2 \\
\hline スポーツ用品・玩具・娛楽用品小売業 & 0 & 4 \\
\hline 他に分類されない小売業 & 0 & 2 \\
\hline 不動産業・賃貸業・管理業 & 0 & 4 \\
\hline 宿泊業 & 0 & 5 \\
\hline 飲食店 & 2 & 10 \\
\hline 持ち帰り・配達飲食サービス業 & 0 & 4 \\
\hline 洗濯・理容・美容・浴場業 & 3 & 4 \\
\hline その他の教育・学習支援業 & 0 & 1 \\
\hline 医療業 & 0 & 1 \\
\hline 社会保険・社会福祉 - 介護事業 & 0 & 2 \\
\hline 郵便局 & 0 & 1 \\
\hline その他のサービス業 & 0 & 1 \\
\hline 合計 & 14 & 60 \\
\hline
\end{tabular}

(現地調查により作成)
3）イオンモール木更津の立地と木更津市との連携 イオンモール木更津は, 店舗面積が $53,000 \mathrm{~m}^{2}$ で木更 津市最大であるとともに，賃貸面積ベースで全国のイ オンモール 128 店中 4 位と, 国内有数の規模を誇る SC である．2014年 10 月に開店し，開業前の9月に「木更 津とイオンとの連携に関する協定」を締結している. この協定には，木更津市の「みなとまち木更津再生プ ロジェクト」に協力するなど，木更津市の活性化と市 民サービスの向上に協働して取り組むと記されている. 立地する地区は都市計画上の工業専用地域であり, $10,000 \mathrm{~m}^{2}$ を超える店舗等は立地できないが，木更津 市が「商業，アミューズメント，スポーツ等を中心と する都市機能を導入」することを目的とする地区計画 を設定することで，立地が可能となった．

木更津市の職員とイオンモール木更津の社員は, 月 に一度の頻度で定例会を開催し, 主にイオンモール木 更津を会場とする木更津市主催の企画を開催している. これについてまとめた表 12 みると，企画の対象は 青少年から高齢者など幅広い年代や身体障害者など, さまざまな対象向けの企画が行われている，また木更 津バルヘイオンモールの専門店が参加するなど，木更 津市のイベントにイオン側が参加する場合もある。 イ オンモールには, スーパーのほか服飾・娛楽・飲食関 連など，幅広い業種の店舗が入居しており，この存在 は，木更津市としては市民の買物環境の向上や定住人 口の増加, 財政の改善に寄与すると考えている ${ }^{12)}$ 。一 方イオンモールとしても, 地域との連携によって幅広 い年齢層の市民向けの企画を開催することにより，幅 広い層の集客が見込めることを期待している ${ }^{13)}$.

現地調査 ${ }^{14)}$ により平日の利用者をみると， $53.7 \%$ が およそ19〜30歳ほどの若者世代，27.4\%がその子ども と考えられる 13 歳未満の世代であり, およそ60歳以 上の高齢者は $7.4 \%$ とわずかである。社会学において も SC は家族連れが多く世代的な多様性は低いといわ れており（南後 2013），イオンモール木更津でも同様 の傾向がみられるが，イオンモールとしては木更津市 と連携をすることにより，これを克服しょうと試みて いる.

4）大型店の利用と消費者行動

木更津市において圧倒的な規模を誇る三井アウト レットパーク木更津とイオンモール木更津の利用実態 
表 12 木更津市とイオンモール木更津との連携内容

Table 12 Cooperation between the Kisarazu city government and AEON Mall Kisarazu

\begin{tabular}{|c|}
\hline 連携内容 \\
\hline $\begin{array}{l}\text { みなとまち木更津再生プロジェクト関連 } \\
\text { デジタルサイネージ等による市政情報の信 } \\
\text { 木更津バルへのイオンール䑤答運航時の送迎バス駐車場の提供など* } \\
\text { クルー揭示* }\end{array}$ \\
\hline $\begin{array}{l}\text { 地域振興関連 } \\
\text { 定住促進プロモーション事業への会場提供 } \\
\text { みなとまち木更津WAONの発行 }\end{array}$ \\
\hline $\begin{array}{l}\text { 地域経済団体の活動への協力・参画関連 } \\
\text { 九都県市クールシェアついてのポスター掲示* } \\
\text { グローカルハピネ時の駐車場提供* } \\
\text { 羽田空港機能強化市民相談会の会場提供* } \\
\text { 日本建築学会関東支部提案競技会の作品展示* }\end{array}$ \\
\hline $\begin{array}{l}\text { 地産地消の推進・木更津産品の販売促進関連 } \\
\text { 木更津マルシェ } \\
\text { かずさファーマーズマーケット* }\end{array}$ \\
\hline $\begin{array}{l}\text { 災害対策・防災・防犯関連 } \\
\text { 安全で安心なまちづくり防犯キャンペーン } \\
\text { 防灭ポスー展および表彰式 } \\
\text { 消防車両の展 } \\
\text { 災害時における一時避難施設としての協定* } \\
\text { 春の火災予防運動のポスター掲示* }\end{array}$ \\
\hline $\begin{array}{l}\text { 商業・観光の振興関連 } \\
\text { サマーミュージックフェス\&花火 } \\
\text { 木更津市景観写真展* } \\
\text { ゆるキャラグランプリのポスター掲示* } \\
\text { 観光PRポスター掲示* } \\
\text { 港まつり花火大会駐車場提供* }\end{array}$ \\
\hline $\begin{array}{l}\text { 健康増進・食育・食の安全関連 } \\
\text { 若年期健康診断 } \\
\text { 食に関する啓発活動 } \\
\text { 国保集団検診ポスターの掲示* } \\
\text { 木更津っ子ダイアリー電子母子帳のポスター掲示* }\end{array}$ \\
\hline $\begin{array}{l}\text { 子育て支援・青少年の健全育成関連 } \\
\text { 全国一斉イベン「ガールスカウトの 2015」 } \\
\text { カブトムシ相撲大会* } \\
\text { 幼児言語教室子育て後援会のポスター掲示 * } \\
\text { 成人式ボスター掲示* }\end{array}$ \\
\hline $\begin{array}{l}\text { 環境保全・緑化推進関連 } \\
\text { 育樹祭およひ植樹祭の開催 }\end{array}$ \\
\hline $\begin{array}{l}\text { 高齢者・障害者の支援関連 } \\
\text { 脳卒中者退院時支援モデル事業に関する大会の開催 } \\
\text { 木更津市あけぼの袁作品展示販売（月1回） } \\
\text { 障害者週間イベントの会場提供* }\end{array}$ \\
\hline $\begin{array}{l}\text { 教育·文化・スポーツの振興関連 } \\
\text { 平成 } 27 \text { 年度全国高等学校総合体育大会市長激励会 } \\
\text { 市政 } 75 \text { 周年ハーフマラソン交通規制について* } \\
\text { 市政 } 75 \text { 周年リレーマラソン大会について* } \\
2017 \text { 木更津トライアスロン大会* }\end{array}$ \\
\hline $\begin{array}{l}\text { その他の連携 } \\
\text { 木更津市景観写真展 } \\
\text { コミュニティー板の活用 } \\
\text { FRESH KISARAZU FESTIVAL } \\
\text { 木更津市新人職員イベント開催会場提供* } \\
\text { 男女共同参画フォーラム会場提供* } \\
\text { ヨル得クーポン } \\
\text { アクアラインマラソンでの駐車場提供 } \\
\text { 潮干狩り場と連携した割引サービス } \\
\text { ブルーベリー園と連携した割引サービス } \\
\text { 花火大会での観覽席の設置 } \\
\text { 中の島大橋バレンタインイントでの会場提供 }\end{array}$ \\
\hline
\end{tabular}

*は2017年度の定例会の議題を意味する.

(聞取り調查および木更津市ホームページにより作成)
を示した表 13 みると，三井アウトレットパークを 月 1 回以上の頻度で利用する人は, 千葉県内の大型店 と比べても 30 位中 11 位とそれほど上位ではないが, 年に数回の利用者および利用率 $5 \%$ 以上のブロック ${ }^{15)}$ 数では 1 位であり, 購入頻度が高くないものの商圈が 広域に及ぶ買回り型の利用傾向がみられる。一方でイ オンモール木更津は, 月 1 回以上の利用率 $(84.4 \%)$ と 立地ブロックの在住者の利用率 $(97.4 \%)$ が1位であ り，近隣住民の利用率が高く利用頻度も多い最寄り型 の利用傾向がみられる。木更津市では, 最寄り型と買 回り型の双方において，千葉県を代表する大型店が立 地していることが分かる.

木更津市の商圈の特性を示した表 14 をると, 2012 年から 2018 年にかけて地元購買率は $4.7 \%$ 上昇, 商圈 人口は 96,598 人増加, 吸引人口は 57,835 人増加, 商圈 内吸引率は $2.8 \%$ 上昇, 吸引力は $38.1 \%$ 上昇しており, この調査・分析結果を示した千葉県商工労働部経営支 援課（2019）では，木更津市を準商業中心都市から商 業中心都市 ${ }^{16)}$ 一昇格したと記している．消費需要の $30 \%$ 以上を吸引する地域は木更津市, 君津市, 富津市, 袖ヶ浦市で，10\%以上 $30 \%$ 未満は鴨川市と鋸南町， $5 \%$ 以上 $10 \%$ 未満は大多喜町, 館山市, 南房総市であり, 木更津市を房総半島南部の中心地として位置づけてい る.

表13 木更津市民による大型店の利用（2018年） Table 13 Use of large retail outlets by Kisarazu residents, 2018

\begin{tabular}{lcr}
\hline 三井アウトレットパーク木更津の利用状況 & \\
\hline 立地ブロックの在住者の利用率 & $84.9 \%$ & {$[5$ 位 $]$} \\
ほとんど毎日〜月に 1 回程度 & $35.9 \%$ & {$[11$ 位 $]$} \\
年に数回 & $49.0 \%$ & {$[1$ 位 $]$} \\
利用率 $5 \%$ 以上のブロック数 & 11 & {$[1$ 位 $]$} \\
\hline イオンモール木更津の利用状況 & & \\
\hline 立地ブロックの在住者の利用率 & $97.4 \%$ & {$[1$ 位 $]$} \\
ほとんど毎日〜月に 1 回程度 & $84.4 \%$ & {$[1$ 位 $]$} \\
年に数回 & $12.9 \%$ & {$[26$ 位 $]$} \\
利用率 $5 \%$ 以上のブロック数 & 6 & {$[13$ 位 $]$} \\
\hline
\end{tabular}

［］は千葉県内の大型店 30 店舗中の順位を示す。立地ブ ロックとは，千葉県商工労働部経営支援課（2019）に打ける 調查単位であり, 千葉県を千葉, 印旛, 葛南, 東葛, 香取, 海匝, 山武, 長生, 夷隅, 安房, 君津の 11 ブロックに分け ている，木更津市は君津市，富津市，袖ヶ浦市とともに君津 ブロックに含まれる。

(千葉県商工労働部経営支援課（2019）により作成) 
表 14 木更津市の商圈の特性

Table 14 Trade areas and consumer behavior in Kisarazu

\begin{tabular}{lrr}
\hline & 2012 年 & \multicolumn{1}{c}{2018 年 } \\
\hline 地元購買率 & $78.4 \%$ & $83.1 \%$ \\
商圈人口 & 361,541 人 & 458,139 人 \\
吸引人口 & 168,423 人 & 226,258 人 \\
商圈内吸引率 & $46.6 \%$ & $49.4 \%$ \\
吸引力 & $129.1 \%$ & $167.2 \%$ \\
\hline
\end{tabular}

地元購買率は衣料品を木更津市内の店舗で購買する割合を, 商圈人口は木更津市が消費需要 $5 \%$ 以上を吸引する市町村の 人口数の合計を, 吸引人口は木更津市人口数に地元購買率を 乗じたものと商圈内各市町村の人口数に木更津市への流出率 を乗じたものの合計を，吸引力は木更津市の人口数に対する 吸引人口の割合を，それぞれ意味する。

(千葉県商工労働部経営支援課（2019）により作成)

なお，2012年の調査結果が掲載された千葉県商工労 働部経営支援課（2013）により，同年に三井アウトレッ トパーク木更津が立地する以前は木更津市内の郊外型 SCとしては店舗面積が最大であったアピタ木更津の利 用状況をみると, 月に 1 回以上の利用は $68.8 \%$ であり， イオンモール木更津と比べると $15 \%$ ほど低い. イオン モール木更津の出店は，木更津市民の大型店の利用を 一層進めたといえる。

2. 中心市街地の商業空間とその課題

1）中心市街地の店舗と利用者の実態

IIIの1.でみたように，木更津市では，2012年以降に 小売業の販売額や売場面積が上昇し, 房総半島南部に 対する商業の中心性も向上したが，それらは三井アウ トレットパーク木更津やイオンモール木更津といった 国内最大級の SCが立地するなど，大型店が立地した 影響が大きい，その中で，かつての商業の中心であっ た木更津駅付近の中心市街地の商業は, どのように変 化したのであろうか. 中心市街地に位置する三つの商 店街における 1994年から 2014年にかけての小売販売 額の推移を示した図 13をみると，2014年には1994年 比で $27.9 \%, 8.8 \%, 1.5 \%$ に減少しており，程度の差はあ るもののいずれも急激に減少している，木更津市企画 部地域政策課（2020）より，中心市街地に扔ける小売 業年間商品販売額と売場面積の木更津市全体に対する 割合をみると，2002年は売場面積で $23.0 \%$ ，販売額で $12.3 \%$ であったのが, 2016年には売場面積で $6.9 \%$, 販 売額で $7.1 \%$ となり, 木更津市全体に対する中心商業地

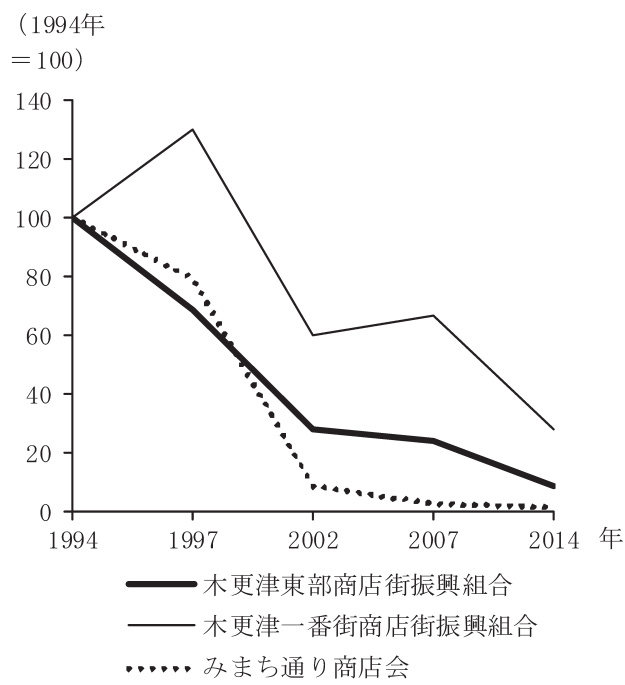

図 13 木更津市中心市街地の商店街における小売販 売額の推移

Fig. 13 Changes in retail sales in shopping streets in the Kisarazu city center

(商業統計調查により作成)

の存在感は小さくなっている. 木更津駅の西口駅前に立 地するスパークルシティ木更津は, 店舗面積 $17,535 \mathrm{~m}^{2}$, 地下 1 階を含む 9 階建ての大型店であるが，三つのフ ロアには市役所, 市議会, ハローワークが入り，その ほか四つのフロアは完全に空きとなっており，厳しい 状況にある中心市街地を象徴する施設といえる.

図10からも分かるように，木更津駅に近い中心市 街地には多くの人が住み，高齢者も多い，特に高齢者 は加齢とともに自家用車に乗れず交通弱者となる可能 性が高く, 徒歩交通圈に食料品や薬品などの生活必需 品を販売する店が必要となる，木更津駅周辺における スーパーおよびドラッグストアの分布を示した図 14 をみると，この一帯ではスーパーやドラッグストアが 近隣に存在しないエリアが広がっている，木更津駅の 西口には地元の農産品などを販売する「ふれあいプラ ザ」が立地していたが，これも2019年3月31日に閉 店した。中心市街地に居住する人々の多くは，所々に 点在するコンビニエンスストアで食料品を購入する場 合も多く ${ }^{177)}$ ，自家用車を利用せずにさまざまな食材を 十分に確保するのは難しい環境にある.

2020年に木更津市が策定した中心市街地活性化基本 計画では，他の多くの地方都市と同様，マンション建 設や部屋の購入に際して補助金を出す「街なか居住」 


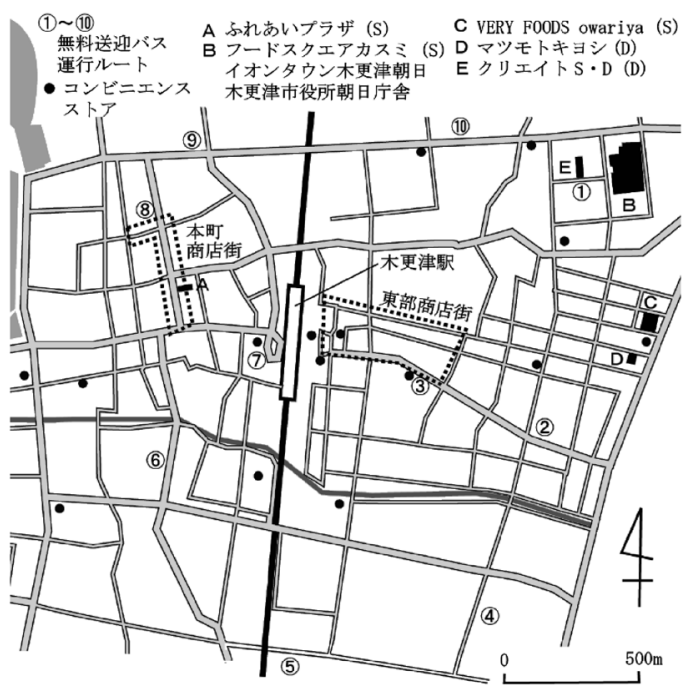

図14 木更津市中心市街地におけるスーパー・ド ラッグストア・コンビニエンスストアの分布

Fig. 14 Distribution of supermarkets, drugstores, and convenience stores in the Kisarazu city center

罒中の（S）はスーパー，（D）はドラッグストアを意味する。 (現地調査により作成)

政策を推進しているが，上記のように近隣における生 活必需品の買物環境が悪いため, マンション建設やそ の部屋の購入が積極的に行われるかは懸念が残る。こ の中心市街地活性化基本計画策定に向けて行われた市 民に対するアンケート調查においても，中心市街地へ 居住する場合の条件として，「ふだんの買い物がしや すいこと」が57.7\% と他の項目 ${ }^{18)}$ に比べて回答率が圧 倒的に高く，日常的な買物環境の改善が中心市街地の 大きな課題となっている.

市区町村ごとの地元商店街の利用状況について, 2012年の調查結果を示した千葉県商工労働部経営支援 課（2013）によると, 商店街の利用頻度として「ほと んど毎日」拉よび「週に2〜3回」の割合は，木更津市 が50.5\%, 千葉県は $41.0 \%$ で, 千葉県に比べても高頻度 に商店街を利用する人の割合は高く，半数に及ぶ．現 在は商店街の店舗が少なく前述の通り木更津市全体に 占める中心市街地の小売販売額もごくわずかであるが, 高齢者も含めて一定数の居住者がいるため, 高齢者を 中心に商店街のニーズはあると考えられる。なお，同 資料より木更津市の商店街を利用する理由をみると， 「価格が安いから」55.7\%（千葉県 37.0\%)，「駐車場が 利用しやすいから」36.8\%（千葉県 $22.1 \%$ ）が千葉県全 体に対して高い值を示している．前者は木更津駅西口
の「ふれあいプラザ」において地元農家が直売する野 菜が相対的に低価格であったこと融が反映されてい ると考えられるが, 同店舗は現在は閉店したため, 商 店街を使う主な理由が失われた可能性もある ${ }^{20}$ ．また 商店街を利用する理由として駐車場の利用しやすさが あげられているが, 前述の中心市街地活性化基本計画 に抒けるアンケート結果でも, 中心市街地への移動手 段として自家用車・社用車が $60.9 \%$ と突出している ${ }^{21)}$. 中心市街地を含め商店街の利用者の多くは，現在は自 家用車を移動手段としているが，IIの2.でみたように 木更津市では高齢化が急速に進んで㧍り，数十年後に は高齢者となった人の多くは自家用車を使うことがで きなくなり，商店街への移動手段がなくなるとも考え られる。

このような状況の中, 中心市街地に立地する個別の 店舗の実態と対応を把握するために，本町商店街と東 部商店街（図 14）に立地する個人商店 24 店舗に聞取 り調査を行った。さまざまな点で商業環境が厳しくな る中で, 特に売上の減少に影響を与えたと考えられる 要因についてまとめた表 15 みると,「大型店の進出」 が10店で最大の回答数であり, 次いで「店主の高齢 化」が7店,「地域経済の衰退」と「通信販売の普及」 が6店で, いずれの要因も多様な業種に影響を与えて いる，IIIの1.でみたように，特に木更津市において大 型店の進出が顕著になるのは, 三井アウトレットパー ク木更津が開業した 2012 年以降であり, 先述の通り中 心市街地ではその以前から店舗や販売額の下落が生じ ているが, 2018年10月現在で残存している店舗は, 特に大型店の立地の影響が大きいと感じている.

中心市街地における買い物弱者の問題は,「フード デザート」問題として扱われるように，生鮮食料品な ど生活必需品の購入先において特に問題になる。 しか しそれ以外の業種の店舗についても，それが身近に存 在しないことは豊かな消費生活を送る上では重要な問 題である. 今回聞取り調査を行った 24 店舗について, 売上の変化と業種との関係を示した表 16 みると, 24店中 6 店舗が上昇・やや上昇・変化なしと回答して おり, 厳しい商業環境の中で比較的経営状況がよい店 舗といえる。これらの業種は居酒屋が2店, 日本料理 店が 1 店, 料亭が1店と 4 店が飲食店である. いずれも 飲酒を想定する店舗であり，比較的高級な店舗も存在 
表 15 木更津市中心市街地の個人商店における売上 減少の要因

Table 15 Factors leading to a decrease in private retail sales in the Kisarazu city center

\begin{tabular}{|c|c|c|}
\hline 減少要因 & 店数 & 業種 \\
\hline 大型店の進出 & 10 & $\begin{array}{l}\text { 本, スポーツ用品, 理容, } \\
\text { 毛糸・布, 花, 日本料理, } \\
\text { 酒場, 日用品・野菜, 呉 } \\
\text { 服, 医薬品 }\end{array}$ \\
\hline 高齢化 & 7 & $\begin{array}{l}\text { スポーツ用品, 毛糸・布, } \\
\text { 美容, 日用品・野菜, 呉 } \\
\text { 服, 医薬品, 化粧品 }\end{array}$ \\
\hline 通信販売の普及 & 6 & $\begin{array}{l}\text { 本, スポーツ用品, 毛 } \\
\text { 糸・布, 花, 本, 呉服 }\end{array}$ \\
\hline 地域経済の衰退 & 6 & $\begin{array}{l}\text { 本, スポーツ用品, 美容, } \\
\text { 居酒屋, 化粧品, 喫茶店 }\end{array}$ \\
\hline 大型店の撤退 & 2 & くつ, 呉服 \\
\hline コンビニの進出 & 1 & 本 \\
\hline スマートフォンの普及 & 1 & スポーツ用品 \\
\hline 消費の多様化 & 1 & 料亭 \\
\hline 歩行者数の減少 & 1 & 美容 \\
\hline 需要の変化 & 1 & 呉服 \\
\hline アクアラインの開通 & 1 & 呉服 \\
\hline 場所・機会の増加 & 1 & 花 \\
\hline モータリゼーション & 1 & 美容 \\
\hline
\end{tabular}

(現地調查により作成)

表 16 木更津市中心市街地の個人商店における売上 の変化と業種の関係

Table 16 Relationship between sales and type of product in private retail outlets in the Kisarazu city center

\begin{tabular}{|c|c|c|}
\hline & 店数 & 業種 \\
\hline 上昇 & 2 & 居酒屋, 陶器 $\cdot$ 金物 $\cdot$ 時計 \\
\hline やや上昇 & 0 & \\
\hline 変化なし & 4 & 料亭, 居酒屋, 日本料理, 毛糸·布 \\
\hline やや減少 & 8 & $\begin{array}{l}\text { く, 理容, 美容, 酒場, 呉服 (2店), } \\
\text { ふすま, 喫茶店 }\end{array}$ \\
\hline 減少 & 9 & $\begin{array}{l}\text { 本 }(2 \text { 店 }) \text {, スポーツ用品, 花, 呉服, 又 } \\
\text { イーツ, 日用品・野菜, 医薬品, 化粧品 }\end{array}$ \\
\hline 無回答 & 1 & \\
\hline 計 & 24 & \\
\hline
\end{tabular}

(現地調查により作成)

する．中心市街地に位置する店舗が影響を受ける SC に入居するテナントには飲食店も多いが，主な移動手 段が自家用車であるために飲酒を前提とした店埔は少 ない。また家族客を主な顧客として想定していると考 えられるため, 大人向けの高級店も少ない. 中心市街 地の個人商店で比較的経営状態がよいのは, SC との 差別化が図られた飲食店といえる.
表 17 木更津市中心市街地の個人商店における売り 上げの変化と工夫の関係

Table 17 Relationship between sales and innovations in private retail outlets in the Kisarazu city center

\begin{tabular}{|c|c|c|}
\hline 売上 & 店数 & 工夫の内容 \\
\hline 上昇 & $2(2)$ & $\begin{array}{l}\text { SNS 活用・修理サービス（陶器・金 } \\
\text { 物・時計), SNS (居酒屋) }\end{array}$ \\
\hline やや上昇 & $0(0)$ & \\
\hline 変化なし & $4(2)$ & $\begin{array}{l}\text { 福祉施設へ納品·SNS 活用 (毛糸· } \\
\text { 布), 公共施設へ卸し · 中小企業診断 } \\
\text { 士と協議 (料亭) }\end{array}$ \\
\hline やや減少 & $8(2)$ & $\begin{array}{l}\text { メーカーとイベント開催 (くつ), 季節 } \\
\text { メニュー・常連との関係強化 (酒場) }\end{array}$ \\
\hline 減少 & $9(4)$ & 学校へ卸 (本 2 店), 配達 (花, 化粧品) \\
\hline 無回答 & $1(0)$ & \\
\hline 計 & $24(10)$ & \\
\hline
\end{tabular}

（）は工夫有の店舗を意味する。

(現地調查により作成)

次に売上と経営上の工夫との関係を示した表 17 を みると，何らかの経営上の工夫を行っている店舗は, 売上が上昇・やや上昇・変化なしと回答した店舗では 6 店中 4店であるのに対して, 売上がやや減少・減少 と回答した店舗では 17 店中 6 店のみである。上昇から 変化なしと回答した店舗の工夫の仕方としては, SNS の活用や修理サービス，公共施設等へ商品を卸す，と いったことが行われている．個人店が残存する背景と して，顧客に対してきめ細かなサービスを提供するこ とや, 行政機関や学校など地域における大口顧客と取 引をすることは, 地方都市における既存の地理学研究 でも指摘されており ${ }^{22)}$ ，木更津でも同様の傾向がみら れる．SNS は高齢な消費者ほど利用する人も少ないと 考えられるが，IIの2.でみたように木更津市で近年増 加している 20４0代の人は, SNSを利用する割合も高 く, 新規顧客を開拓する手段として有効と考えられる.

2）イオンタウン木更津朝日と無料送迎バスの利用 木更津市中心市街地の主要な買物先の一つとして, イオンタウン木更津朝日がある。核店舗であるスー パー・カスミのほか，40店ほどの店舗や施設が入る 小規模 SCである（図14）。このSCの2階フロアには, 2015 年以降木更津市役所朝日庁舎として，特に市民 と関わる頻度が高い市民課，保険年金課，高齢者福祉 課といった部署が配置されている，入居に至る背景に は，この 2 階フロアが空いていたことのほか，市民の 買物利便性の向上，後述する無料送迎バスや駐車場の 
存在などがあげられる ${ }^{23)}$.イオンタウン側としても, 市役所機能が入ることにより固定客を獲得することが できると考えられる24)

イオンタウン木更津朝日が運営している無料送迎バ スは, 同 SCのほか, 木更津駅西口を含む中心市街地を およそ50分で一周し，1時間に 1 本程度運行している. 利用目的に関係なく無料で利用できる.SCの付近に は，この無料送迎バスのほか，小湊鉄道が運行する二 つの路線バスの停留所があるが, 平日の三つの停留所 におけるお抢よその年齢別乗降者数を示した図 15 をみ ると，無料送迎バスの利用者のほとんどは 60 歳以上 の高齢者であり，これが中心市街地付近に居住する高 齢者にとって重要な移動手段となっていると考えられ る.この調査日における無料送迎バスの乗降客数は 165 名であるが, 並行する路線バス A 29 名, 路線バ ス Bは0名であった．無料送迎バスと並行する路線バ ス $\mathrm{A}$ は利用者が少なく採算が取れないが，中心市街地 の外側に居住する住民にとって重要な移動手段である ため，木更津市が補助金を支出して維持している。 ま たこの無料送迎バスは集客を目的とした特定の民間企 業が運営していることもあり，行政は木更津市民に対 する周知を積極的に行うことができず25)，木更津駅構 内にそのバス停の位置等の説明がないなど課題が残 る.

現地調査によりイオンタウン木更津朝日の平日の利 用者をみると ${ }^{26)}, 23.4 \%$ がおよそ 60 歳以上の高齢者, $34.8 \%$ がおよそ 40～ 50 代の中高年層であり，III の 1.の

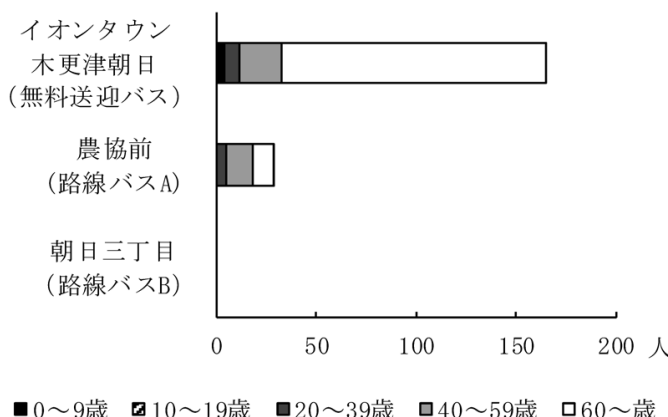

図 15 イオンタウン木更津朝日付近のバス停の乗降 者数

Fig. 15 Number of passengers using the bus stop near AEON Town Kisarazu Asahi

2018 年 10 月 3 日 (水) 1 日（10:10～16:52）の乗降者数を示す. (現地調查により作成)
3）でみたようにイオンモールが 19～30 代の若者や 12 歳以下のその子ども世代が多かったこととは対照的に, 中高年層や高齢者の利用が多い。この施設内にある共 有スペースの利用状況を示した表 18 みても，38組の 利用者のうち 60 歳以上とみられる女性を含むグルー プが33組ある。このSCが高齢女性を中心に利用され ているとともに，共有スペースは知人と交流する場と して使われている。無料送迎バスが存在し，市役所で の手続きと買い物が同時にできて利便であるため，自 家用車が運転できない高齢女性を中心に利用され，彼 女たちにとって重要なコミュニティスペースとして機 能していると考えられる.

\section{3. 郊外住宅地の商業空間}

最後に，木更津市において再開発が進行する郊外住

表18 イオンタウン木更津朝日における共有空間の 利用

Table 18 Use of shared space in AEON Town Kisarazu Asahi

\begin{tabular}{|c|c|c|c|}
\hline & 場所 & 組合せ & 組数 \\
\hline \multirow[t]{8}{*}{$10: 30$} & A & 60 歳以上女 2 人組 & 2 \\
\hline & A & 60 歳以上女 3 人組 & 1 \\
\hline & A & 60 歳以上女 4 人組 & 3 \\
\hline & A & 60 歳以上女 3 人と 60 歳～男 1 人組 & 1 \\
\hline & A & 60 歳以上女 4 人と 60 歳〜男 1 人組 & 1 \\
\hline & $\mathrm{B}$ & 60 歳以上女 3 人組 & 1 \\
\hline & $\mathrm{B}$ & 60 歳以上女 5 人組 & 1 \\
\hline & $\mathrm{C}$ & 60 歳以上女 2 人組 & 1 \\
\hline \multirow[t]{5}{*}{ 11:00 } & A & 60 歳以上女 2 人組 & 2 \\
\hline & A & 60 歳以上女 3 人組 & 1 \\
\hline & A & 60 歳以上女 4 人組 & 3 \\
\hline & B & 60 歳以上女 3 人組 & 1 \\
\hline & B & 60 歳以上女 4 人組 & 2 \\
\hline \multirow[t]{7}{*}{ 12:00 } & A & 40～59歳夫婦 & 2 \\
\hline & A & 40～59歳女 2 人組 & 1 \\
\hline & A & 幼児連れ 20～39歳女 2 人組 & 1 \\
\hline & A & 60 歳以上女 2 人組 & 2 \\
\hline & A & 60 歳以上女 4 人組 & 2 \\
\hline & B & 60 歳以上女 2 人組 & 3 \\
\hline & B & 60 歳以上女 3 人組 & 1 \\
\hline \multirow[t]{3}{*}{ 13:00 } & A & 40～59歳女 2 人組 & 1 \\
\hline & A & 60 歳以上女 2 人組 & 2 \\
\hline & A & 60 歳以上女 5 人と 60 歳以上男 1 人組 & 1 \\
\hline \multirow[t]{2}{*}{$15: 30$} & A & 60 歳以上女 2 人組 & 1 \\
\hline & B & 60 歳以上女 4 人組 & 1 \\
\hline 合計 & & & 38 \\
\hline
\end{tabular}

$\mathrm{A}$ は 1 階フードコート， B は 1 階フードコート前， C は 2 階フ リースペースを指す。

（2018年 10 月 5 日 (金) の現地調查により作成) 
宅地付近の商業空間についてみる。木更津駅から南東 に2.8 km 離れた場所に, 再開発によって造成された請 西南の住宅地がある（図2）。標高約 $50 \mathrm{~m}$ の丘陵地上に 位置し，西に木更津南インターチェンジがあり東京方 面への自家用車でのアクセスも容易である。1991年に 土地区画整理事業が施行され，2007年に終了し宅地分 譲が順次開始された。国勢調査をみると，2015年には $1 丁$ 目から $5 丁$ 目にかけて 4,349人が居住している。住 宅地の中心には, イオン系食品スーパーのマックスバ リュを核店舗とし，27店ほどの店舗や施設が入る小規 模 SC イオンタウン木更津請西がある．またこれに至 る主要道路沿いや，住宅地内に広がる裏通り沿いにも 店舗が立地している。

これまでみてきたように，木更津市内の SCの施設 内やその周辺に立地する店舗など，消費者によって利 用される店舗の多くは大手企業が経営するチェーン店 であり，木更津市民はチェーン店を中心とした消費生 活を送っていると考えられる，その中で，イオンタウ ン木更津請西の周辺には多くの個人商店も立地してい る. イオンタウン木更津請西および周辺地域の業種別 店舗数とチェーン店数を示した表 19 をると, 主要道 路 $^{27)}$ 沿いでは 33 店中 13 店, それ以外では 20 店中 1 店 がチェーン店で，その他は個人経営の店舗であり，こ の地域には個人商店が多く立地している。これらのほ とんどは住居併設の店舗で, 店舗の前には駐車場があ り，利用者の多くは自家用車を利用していると考えら れる，たとえば契茶店を経営する個人店の一つは，北 欧の料理や食品を提供し，4台の駐車スペースがある. 近くにチェーン店のコメダ珈琲店があるが，利用者の ニーズが異なるため影響は少ないと感じている，同じ くケーキを主に扱う洋菓子店は 2 台の駐車スペースが ある，両店ともに，主な顧客は近隣住民であるが，通 りかかった遠方からの顧客が来店する場合もあるとい $j^{28)}$ ． 木更津市に立地する多くの店舗は大手企業が経 営するチェーン店で, 消費者は一律の商品やサービス を購入するなど，均質的な消費生活を送っているが ${ }^{29)}$, 郊外住宅地の居住者を中心に, 近隣の個人商店で差別 化された消費生活を送っている側面もあると考えられ る。
表19 イオンタウン木更津請西とその周辺に立地す る店舗の特徴

Table 19 Features of retail outlets located in and around AEON Town Kisarazu Jozai

\begin{tabular}{|c|c|c|c|}
\hline & $\begin{array}{c}\text { イオンタウン } \\
\text { 木更津請西 }\end{array}$ & 主要道路 & $\begin{array}{c}\text { 主要道路 } \\
\text { 以外 }\end{array}$ \\
\hline スーパー・コンビニエンスストア & $1(1)$ & $3(3)$ & $0 \quad(0)$ \\
\hline 飲食料品小売 & $1(1)$ & $2(1)$ & $1(0)$ \\
\hline 衣料品・身の回り品 & $4(2)$ & $0(0)$ & $2(0)$ \\
\hline 生花·生活雑貨 & $1(1)$ & $1(0)$ & $0(0)$ \\
\hline 家具·家電小売 & $1(1)$ & $0(0)$ & $0(0)$ \\
\hline 自転車小売 & $1(1)$ & $0(0)$ & $0(0)$ \\
\hline 教育施設 · 学習塾 · 文化教室 & $3(3)$ & $3(0)$ & $2(0)$ \\
\hline 喫茶店 & $2(2)$ & $0(0)$ & $1(0)$ \\
\hline 飲食サービス & $0(0)$ & $4(4)$ & $4(0)$ \\
\hline 医院·歯科 & $2(0)$ & $5(0)$ & $1(0)$ \\
\hline 薬局·医薬品 & $0(0)$ & $3(3)$ & $1(1)$ \\
\hline 理容·美容院 & $2(1)$ & $2(0)$ & $4(0)$ \\
\hline ペット関連サービス & $1(1)$ & $2(0)$ & $2(0)$ \\
\hline 介護・福祉サービス & $0(0)$ & $1(1)$ & $0 \quad(0)$ \\
\hline リラクゼーション & $2(0)$ & $2(0)$ & $1(0)$ \\
\hline 娛楽施設 & $3(3)$ & $0(0)$ & $0 \quad(0)$ \\
\hline 生活関連サービス & $2(2)$ & $3(1)$ & $0 \quad(0)$ \\
\hline その他 & $2(2)$ & $2(0)$ & $1(0)$ \\
\hline 合計 & $28(21)$ & $33(13)$ & $20(1)$ \\
\hline
\end{tabular}

請西南 1 5 丁目の店舗数を示す.（）内の数值はチェーン 店の数を示す. 主要道路とは, イオンタウン木更津請西を挟 んで南西方面から北東方面へ伸びる二つの道路を意味する。

\section{IV まとめと考察}

本研究では, アクアラインの開通とその通行量の増 加により, 大きな変化をみせている千葉県木更津市を 対象に, 交通・人口・商業の面から地域の変化やアク アライン開通後の地域の特徵と構造を明らかにすると ともに，地域的課題について考察した．今日の木更津 市の特徵・構造と課題についての模式図を図16に示 す.

アクアラインはその料金の低価格化によって通行量 が増加した，通勤時間の短縮や低価格な費用，着席で きる快適性を背景に，木更津方面と東京都心部および 川崎方面を結ぶ高速バスが利用され，東京大都市圈郊 外における相対的な地価の安さも相まって，木更津市 ではこの方面へ通勤する人口が増加した，高速バスの 利用には，自家用車をバスターミナル付近の駐車場へ 止めてバスで通勤するパーク\&ライドが行われる場合 も多い。また人口増加の主要な受け皿となったのは, 木更津市郊外のインターチェンジ付近や主要道路沿い に再開発された住宅地であった。

アクアラインの通行量増加により, 木更津市では, 


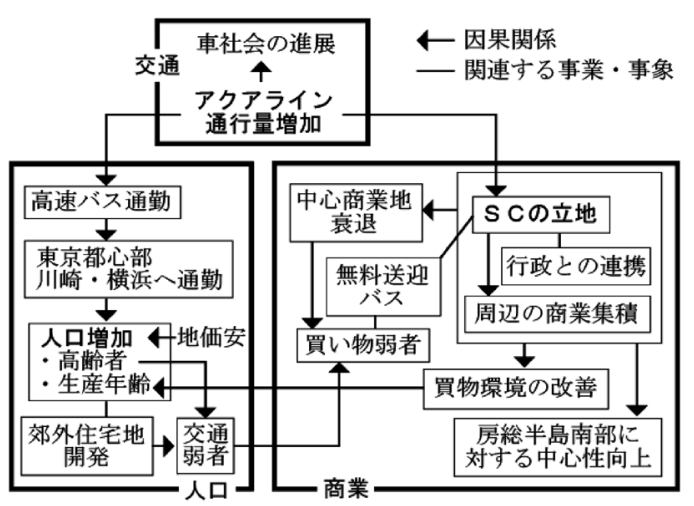

図16 アクアライン開通後の木更津市の地理的特徵・ 構造と地域的課題の模式図

Fig. 16 Schematic diagram of Kisarazu's geographic features and structural and regional issues after Aqua-Line opening

市による地区計画の実施など行政の協力や連携のもと ${ }^{30)}$, $\mathrm{SC}$ な゙の大型店が開業し，その周辺にチェーン店な どが集積したことで，房総半島南部に対する商業中心 性が向上した。これらは木更津市民に対する買物環境 の向上に寄与し, これが木更津市の魅力となり人口増 加の背景の一つになっていると考えられる.

しかし大型店やその周辺のチェーン店の多くが中心 市街地から離れた場所に位置するため, もともと苦し い状況にあった中心市街地の個人商店はさらに厳しい 状況にある. 中心市街地にはスーパーやドラッグスト アといった生活必需品を販売する店舗も少なく，買い 物弱者が発生している。この改善のために木更津市と しては小規模な食品スーパーなどが立地することを望 んでいるが，すでにイオン系列店が3店市内に立地す るため, 系列店間での競合を避けたいイオンとしては 立地しづらい ${ }^{31}$. また他の企業に対しても, 木更津市 とイオンとのつながりが強いために積極的な誘致がし づらいと考えられ, 問題解決への道筋が立たない状況 にある。

木更津市では高齢化が進展し，今後はさらに高齢者 が増加すると考えられるため, 数十年後には自家用車 の運転が困難となり, 多くの交通弱者や買い物弱者が 発生する可能性が高い. 彼ら・彼女らの移動手段の一 つとなっているのが, SCが運営し中心市街地を一周 する無料送迎バスである．しかしこの存在により，並 行する民間会社のバス路線の運営が困難となっている. また無料送迎バスが商業系の民間企業による運営のた
めに，市民へ積極的に周知できないことも課題となっ ており，イオン頼りの弊害がここにも表れている.

加えて，木更津市民が利用する主な店舗は，SCや その周辺に立地し全国的に一律の商品やサービスを提 供するチェーン店であるため, 差別化されていない均 質的な消費生活を送らざるを得ない商業環境にあると いえる。オリジナルな商品やサービスを提供する個人 商店は, チェーン店との差別化を図っている中心市街 地の飲食店や郊外住宅地の付近でみられるが，木更津 市の商業全体に対する割合は小さい.

以上のように木更津市は, アクアラインの開通とそ の通行量の増加によって，人口は増加し商業中心性は 向上しているが，通勤や買い物といった日常生活が自 家用車の使用を前提とした地域構造となっているた め, 高齢化が進んでいる今日では大きな課題を抱えて いる．アクアラインは，ETCを搭載する普通車の通 行料金を 800 円とする社会実験が続けられ，千葉県と 国がそれぞれ5億円を負担しているが ${ }^{32)}$ ，これも将来 的に継続されるかは未知数であり，木更津市も現在の 地域的特徵や地域構造を維持し続けるか否かの見通し も不透明である。また世界的スケールで環境問題の解 決に向け，自家用車に依存しない生活やそれを可能と する市街地形成が求められる今日においては, $\mathrm{CO}_{2}$ を いかに削減するかも大きな課題といえる.

\section{謝 辞}

本研究は，2018年10月に木更津市において実施し た現地調査と，その成果として筆頭著者を除く6名が 2019年 1 月に東京学芸大学地理学分野へ提出した進級 論文を基に，筆頭著者の牛垣が大幅に加筆・修正・再 構成したものである，現地調査においては，木更津市 役所，イオンモール(株) やイオンタウン(株)，日東 交通，東部商店街および本町商店街振興組合，店舗を 経営されている皆様に, 多大なるご協力を賜りまし た。ここに記してお礼申し上げます。

この研究は, 2019年11月の日本大学地理学会秋季 学術大会および 2020 年 3 月の日本地理学会春季学術大 会での発表を骨子とし，その後に加筆・修正をしたも のである. 
注

1）地価情報センターによる都道府県地価調査では, 1999 年から 2003 年にかけての平均地価（全用途） の上昇率が，木更津市は $-56.7 \%$ で，市町村合併 等で計算できない自治体を除く全1,406市区町村 中ワースト 2 位である。なおワースト 1 位は千葉 県九十九里町であり，ワースト20のうち16を千 葉県内の自治体が占める.

2）前掲 1）の資料によると，2006年から 2014年にか けての平均地価の上昇率が，木更津市は $+2.6 \%$ で，市町村合併等で計算できない自治体を除く全 1,803 市区町村中で 171 位と，上位に位置する.

3）東京大都市圈における通勤行動を分析した従来の 研究（斉藤 1982; 駒木 2004）をみても，木更津 市は東京大都市圈の圈外に位置している。

4）2000年から 2015年の間に合併した市町村を除く.

5）市原市，袖ヶ浦市，君津市に次いで通勤者が多い のは県庁所在地の千葉市である．東京大都市圈の 通勤行動を分析した駒木（2004）や高井（1998） に挍いても，木更津市は千葉市の通勤圈内である ことを示している.

6） 2005 年の時点に打いても，木更津市の 15 歳以上 就業者の通勤先は, 上位から君津市 (6,764人), 市原市 $(4,284$ 人) , 袖ヶ浦市 $(3,956$ 人) , 千葉市 (3,257人) と続く.

7）統計の数值は就業者と通学者が含まれるが，2015 年の木更津市では 15 歳以上県外就業者が 4,292 人, 同通学者が 715 人であり， $85.7 \%$ は就業者による 通勤が占めるため，ここでは通勤として扱う.

8）この間に新設された町丁の 2015 年の人口数は 13,407 人, 同町丁の 2005 年の旧町の人口数は 517 人である。

9）千葉県統計年鑑による。自動車は, 乗用自動車 (普通車＋小型車）＋軽自動車の值である.

10） 2015 年の国勢調査により持ち家世帯割合をみると, 新設町丁は $59.7 \%$, 既存町丁は $66.5 \%$, 木更津市 全体では $65.8 \%$ であり，新設町丁で特に持ち家世 帯が多いわけではない，高齢化に伴い居住地を変 更する可能性もあるが，6割は持ち家であるため， 今後一定数の高齢者が郊外に居住することになる と考えられる。
11）根本（2013）は，品川への通勤時間で同距離の東京 西郊と比べると，木更津市の住宅価格は 10 分の 1 程度と指摘する。

12）木更津市役所経済部産業振興課への聞取り調査に よる.

13）イオンモール(株) への聞取り調查による.

14） 2018 年 10 月 4 日(木) の 15 時 45 分から 16 時 15 分 の30分間において，同施設でメインとなるアクア パーク入口と駐車場から近いゲートパーク入口で 調查を行い, 95 人が通行した.

15）ブロックとは，千葉県商工労働部経営支援課 (2019) に打ける調查単位であり，千葉県を千葉，印旛， 葛南, 東葛, 香取, 海匝, 山武, 長生, 夷隅, 安 房，君津の 11 ブロックに分けている，木更津市は 君津市，富津市，袖ケ浦市とともに君津ブロック に含まれる。

16）千葉県商工労働部経営支援課（2019）では，中心 都市を商業中心都市（千葉市・成田市・印西市・ 船橋市・柏市・木更津市)，準商業中心都市（市 原市・東金市・茂原市・館山市)，単独商圈都市 （八千代市・佐倉市・松戸市・野田市・銚子市） に区分している.

17）木更津市役所経済部産業振興課に対する聞取り調 查による.

18）そのほか「福祉・医療機関が充実していること」 $23.3 \%$ ，「治安や防災面で安全であること」16.7\%， 「公共機関が充実していること」14.1\%，「住宅価 格・家賃が手ごろであること」 $13.6 \%$ ，「まちに清 潔感があり綺麗なこと」 $11.3 \%$ ，「子育て環境が充 実していること」5.2\%，「港や道路が整備されて いること」4.7\%,「その他」3.7\%が続く.

19）ふれあいプラザに関する資料による。 http://www. landbrains.co.jp/chiikiryutsu/dl/01-chiba-kisarazu.pdf （最終閲覧日：2020年 5 月 4 日）

20）新千葉新聞2019年 3 月 23 日掲載記事によると, 地域住民にとってなくてはならない便利な店が急 に閉店したため，運営主体である商店街振興組合 に対して地元自治会が説明を求めている.

21）そのほか, バス $7.2 \%$, 徒歩 $6.4 \%$, 自転車 $5.1 \%$, 電車 $3.2 \%$, タクシー $0.9 \%$, バイク $0.8 \%$ ，その他 $0.2 \%$ が続く. 
22）大石ほか (2011), 市川ほか (2013), 田上・牛坦 （2018）など.

23）木更津市役所経済部産業振興課に対する聞取り調 査による。

24）イオンタウン (株) に対する聞取り調査による.

25）木更津市総務部管財課に対する聞取り調査による.

26） 2018 年 10 月 3 日(水) の 15 時 45 分から 16 時 15 分 の 30 分間において, 同施設の核店舗であるカスミ や駐車場および無料送迎バス停留所に近いモール 南入り口で調査を行い, 132 人が通行した.

27）主要道路は, 比較的通行量の多いイオンタウン木 更津請西を挟んで南西方面から北東方面へ伸びる 二つの道路を意味する。

28）2018年10月に実施した店舗での聞取り調査によ る.

29）全国的ないし世界的なチェーン店の展開に伴う消 費生活や商業空間の均質化については, リッ⿻ア (1999)，三浦 (2004)，牛坦 (2015)，牛垣ほか （2016）などを参照されたい.

30）箸本・米浜 (2009) は, 太田市と佐野市を対象に, $\mathrm{SC}$ の進出に際する用途地域の変更など自治体の 対応について考察した.

31）イオンタウン(株) に対する聞取り調査による.

32）日本経済新聞 ONLINE2013年12月21日付記事に よる. https://www.nikkei.com/article/DGXNZO6439 0140Q3A221C1 L71000/（最終閲覧日：2020年 8 月 30 日）

\section{文 献}

石川雄一 2008. 『郊外からみた都市圈空間——郊外 化・多核化のゆくえ』海青社.

磯部 作 1985. 瀬戸大橋の地域経済に与える影響. 経済地理学年報 31: 52-65.

市川康夫 · 周 雯婷 - 金子 愛 - 高橋 淳 - 劉 玲 中村昭史・山下清海 2013，地方小都市における商 業の役割と機能一一富山県入善町中心市街地を事例 に. 人文地理学研究 33: 29-66.

牛垣雄矢 2015. 日本における商業空間の性格とその 変化に関する一考察——盛り場からショッピングセ ンターにいたる空間的性格の変遷より. 東京学芸大 学紀要 人文社会科学系 II 66: 49-64.

牛垣雄矢 - 木谷隆太郎 - 内藤 亮 2016. 東京都千代 田区秋葉原地区における商業集積の特徵と変化— 2006年と 2013 年の現地調査結果を基に. E-journal
GEO 11: 85-97.

江崎雄治 2006.『首都圈人口の将来像——都心と郊外 の人口地理学』専修大学出版局.

大石貴之・津田憲吾 - 常木正道 - 神谷隆太 - 財津克 裕・巌 婷婷 2011. 須坂市中心商店街における商 業機能の変容と商店の対応. 地域研究年報 33: 177195.

川久保篤志 1996. 瀬戸大橋開通と中四国地方におけ る物流拠点の再編一一岡山県総合流通センターを事 例に. 新地理 44(2): 17-28.

木更津市企画部地域政策課 2020。『木更津市中心市街 地活性化基本計画』.

駒木伸比古 2004. 通勤・消費行動からみた東京大都 市圈の空間構造. 新地理 52(1): 1-15.

駒木伸比古 2010. 徳島都市圈における大型店の立地 展開とその地域的影響一一型店の出店規制に着目 して. 地理学評論 83A: 192-207.

五味武臣 1984. 石川県鹿島郡能登島町における能登 島大橋架橋に伴う地域変容. 金沢大学教育学部紀要 人文科学・社会科学編 33: 31-34.

斉藤一弥 1982. 東京大都市圈の社会 - 経済的地域構 造. 人文地理 34: 363-377.

杉村暢二 1991. 坂出の市街化と商業中心地の動向 一瀬戸大橋開通の影響も併せて. 不動産研究 33 (3) : 10-20.

鈴木晃志郎 2014. 住民意識にみる公共事業効果の 「神話」性とその構成要因一一輔の浦港湾架橋問題 に関するアンケート調査結果を用いて，歴史地理学 56(1): $1-20$.

鈴木晃志郎・鈴木玉緒・鈴木 広 2008. 景観保全か 地域開発か—鞆の浦港湾架橋問題をめぐる住民運 動. 観光科学研究 1: 51-69.

高井健太郎 1998. 東京大都市圈における人口移動と その地域パターン。新地理 45(4): 17-33.

谷 謙二 2002. 1990年代の東京大都市圈における通 勤流動の変化に関するコーホート分析．地理学研究 報告 22: 1-21.

谷 謙二 2005. 東京大都市圈における1990年代の通 勤流動の変化と若者断線の就業行動——埼玉県上尾 市居住者の事例. 埼玉大学教育学部地理学研究報告 25: 20-30.

田上拓信 - 牛垣雄矢 2018. 下田市中心商店街の特徵 と厳しい商業環境に対する商店の対応，新地理 66 (2): 22-33.

千葉県商工労働部経営支援課 2013。『千葉県の商圈 平成 24 年度 消費者購買動向調査報告書』.

千葉県商工労働部経営支援課 2019.『千葉県の商圈 平成 30 年度 消費者購買動向調査報告書』.

南後由和 2013. 建築空間/情報空間としてのショッ ピングモール．若林幹夫編『モール化する都市と社 会——巨大商業施設論』119-190. NTT出版.

根本祐二 2013。『豊かな地域」はどこがちがうのか 一地域間競争の時代』筑摩書房.

箸本健二・米浜健人 2009 . 郊外型大型店の進出をめ 
ぐる地方自治体の対応一太太田市と佐野市の事例を もとに. 早稲田大学教育学部 学術研究 (地理学. 歴史学・社会科学編) 57: 49-67.

藤塚吉浩 2000. 本四架橋後の地方都市中心市街地の 変容——高知市における人口移動分析を中心に。地 理科学 55: 159-168.

堀本雅章 2011. 架橋に対する住民意識——沖縄県本 部町水納島と宮古島市大神島を比較して．沖縄地理 11: 55-63.

堀本雅章 2012. 沖縄県野甫島民の架橋および空路に 対する島民意識. 沖縄地理 15: 77-84.

堀本雅章 2017. 観光地化した島に架橋は必要か否か 一沖縄県竹富町鳩間島の事例。地理空間 10: 29-40.

前畑明美 2011. 沖縄・古宇利島における架橋化によ
る社会変容. 人文地理 63: 344-359.

三浦 展 2004.『ファスト風土化する日本一一郊外化 とその病理』洋泉社。

宮澤 仁・阿部 隆 2005. 1990年代後半の東京都心部 における人口回復と住民構成の変化一一国勢調查小 地域集計結果の分析から. 地理学評論 78: 893-912.

矢部直人 2003.1990 年代後半の東京都心における人 口回帰現象一一港区における住民アンケート調查の 分析を中心にして. 人文地理 55: 277-292.

リッッア, G. 著, 正岡寬司監訳 1999.『マクドナルド 化する社会』早稲田大学出版部. Ritzer, G. 1996. The McDonaldization of society: An investigation into the changing character of contemporary social life, rev. ed. California: Pine Forge Press.

\section{〈著者略歴〉}

牛垣 雄矢（うしがきゆうや）

東京学芸大学准教授. 日本大学文理学部助手, 同助教, 東京学芸大学講師を経て, 現職. 都市の商業や地域研究 を専門とする．主な著書は，「東京の都心周辺地域における土地利用の变遷と建物の中高層化一新宿区神楽坂地 区を事例に一」(2006年，地理学評論 79: 527-541),「東京都千代田区秋葉原地区に抢ける商業集積の特徴と変化 一2006年と 2013 年の現地調査結果を基に一」(2016年, E-journal GEO 11: 85-97, 木谷隆太郎・内藤 亮と共著), 「銚子市に扔ける中心商業地の実態と課題一特に飲食店と空き店舖の活用に着目して一」(2019年，学芸地理 75: 1-15, 市野裕貴・高橋和宏・森 和音と共著), 「身近な地域の地誌一神奈川県川崎市の地域調查一」(2020年, 矢ケ㠃典隆・加賀美雅弘・牛垣雄矢編『地誌学概論（第2版）』10-18．朝倉書店）など.

東京学芸大学・都市地理ゼミホームページ：https://bullurbangeo.jimdofree.com/

久保 薰(くほ か抢る)

東京都公立中学校勤務.

坂本 律樹（さかもとりつき）

東京学芸大学在学中.

関根 大器（せきね たいき）

エネルギー関連企業勤務.

近井 駿介（ちかいしゅんすけ）

東京都公立小学校勤務.

原田怜於（はらだれお）

埼玉県立高等学校勤務.

松井 彩桜（まつい さくら）

東京都公立小学校勤務. 